\title{
Memento mori Inkoon keskiaikaisessa kirkossa
}

Janika Aho

Käsittelen tässä artikkelissa Inkoon kirkon pohjoisseinänällä säilyneitä myöhäiskeskiaikaisia memento mori -aiheita. ${ }^{1}$ Näistä tunnetuin on katkelmallisena säilynyt kuolemantanssia kuvaava aihe (Kuva 1 ja 2), jossa kulkuemaisesti edeten tanssivat ruumiit johdattavat eri yhteiskuntaluokkien edustajia. Inkoon Kuolemantanssia on käsitelty aikaisemmassa tutkimuksessa lyhyesti. ${ }^{2}$ Kuitenkin lähes vaille huomiota ovat jääneet Kuolemantanssin ohella esiintyvät kaksi muuta elämän epävarmuudesta ja sen päättymisen varmuudesta muistuttavaa, Kuolemantanssin länsipuolella sijaitsevaa kuva-aihetta. Nämä ovat Elämänpyörä (Kuva 3), jossa kohtaloa tai onnen allegoriaa, Fortunaa, kuvaavan suuren pyörän kyydissä on mies- hahmoja; yksi nousemassa pyörän kyytiin, toinen pyörän huipulla ja kolmas mies tippumassa rattaan kyydistä neljännen maatessa maassa ruumiina. Elämänpyörän länsipuolella sijaitsee ylpeyden syntiä kuvaava aihe Kuolema sahaamassa puuta (Kuva 4ab). Siinä muodikkaasti pukeutunut nuorukainen tähyää puun latvassa tietämättömänä alhaalla puuta poikki sahaavasta kuoleman ruumiillistumasta. Näiden yläpuolella on lisäksi sijainnut naista ja paholaista kuvaava, sittemmin kalkin alle jätetty Kenkä-Ella -aihe. ${ }^{3}$ Yhdessä nämä kuvat ovat muodostaneet moraalista ja hyvästä elämästä sekä kuolemasta muistuttavan kokonaisuuden.

Inkoon Kuolemantanssi on ainoa tunnettu ja nykypäivään säilynyt kuolemantanssikuva keskiaikaisen Ruotsin valtakunnankuningaskunnan alueella. ${ }^{4}$ IInkoon maalaukset löydettiin vuonna 1894, mutta suuri osa niistä peitettiin uudestaan vuonna 1896 ja vain kuorin maalaukset sekä Kuolemantanssi restauroitiin. ${ }^{5}$ Elämänpyörä ja Kuolema sahaamassa puuta -aihe ovat sen sijaan löytyneet vasta vuosina 1987-1988 tehtyjen kirkon korjaustöiden ja maalausten konservoinnin yhteydessä, eikä näitä aiheita ole käsitelty tieteellisessä julkaisussa ennen käsillä olevaa artikkelia. ${ }^{6}$

Inkoon Kuolemantanssista on julkaistu kaksi artikkelia. Helena Edgrenin "The Dance of Death in Inkoo: A Medieval Church Painting As as a Source of Local History" (1989) analysoi aiheen hahmoja ja yhteyttä Inkoon historian tapahtumiin. Cora Dielin "Ein Abglanz Notkes? Der Totentanz Von Inkoo Im Hanseatischen Kontext" (2000), perustuu Inkoon Kuolemantanssin vertailuun ranskalaista danse macabre -perinnettä ja saksankielisen Itämeren alueen Totentanz-kuvastoa vasten. Kummassakaan edellisistä ei mainita Elämänpyörää tai Kuolema sahaamassa

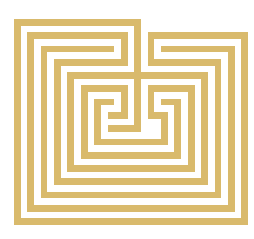




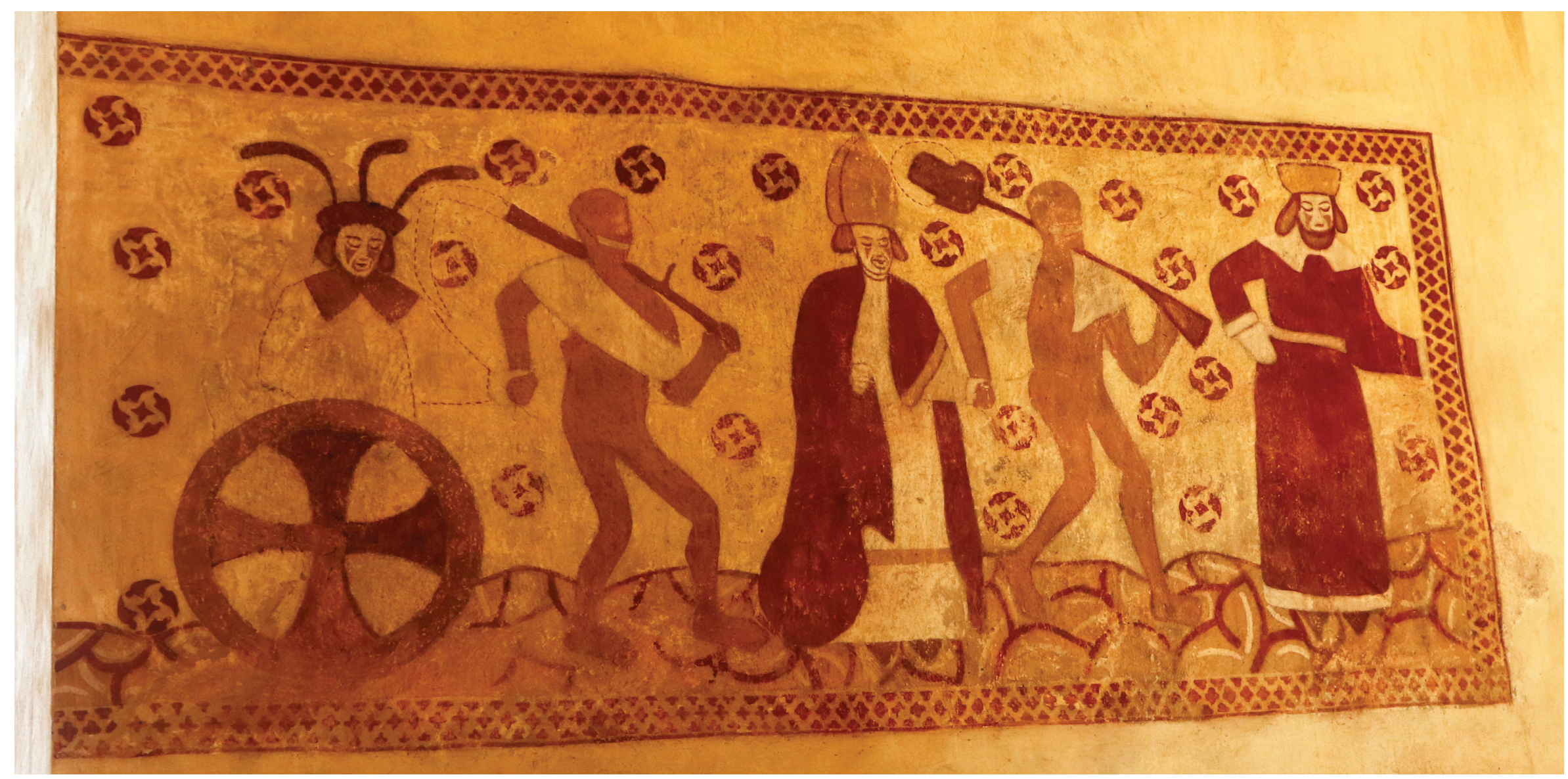

Kuva 1. Kuolemantanssin itäinen osa, noin 1510-luku. Inkoon kirkko. Kuva: Janika Aho. 


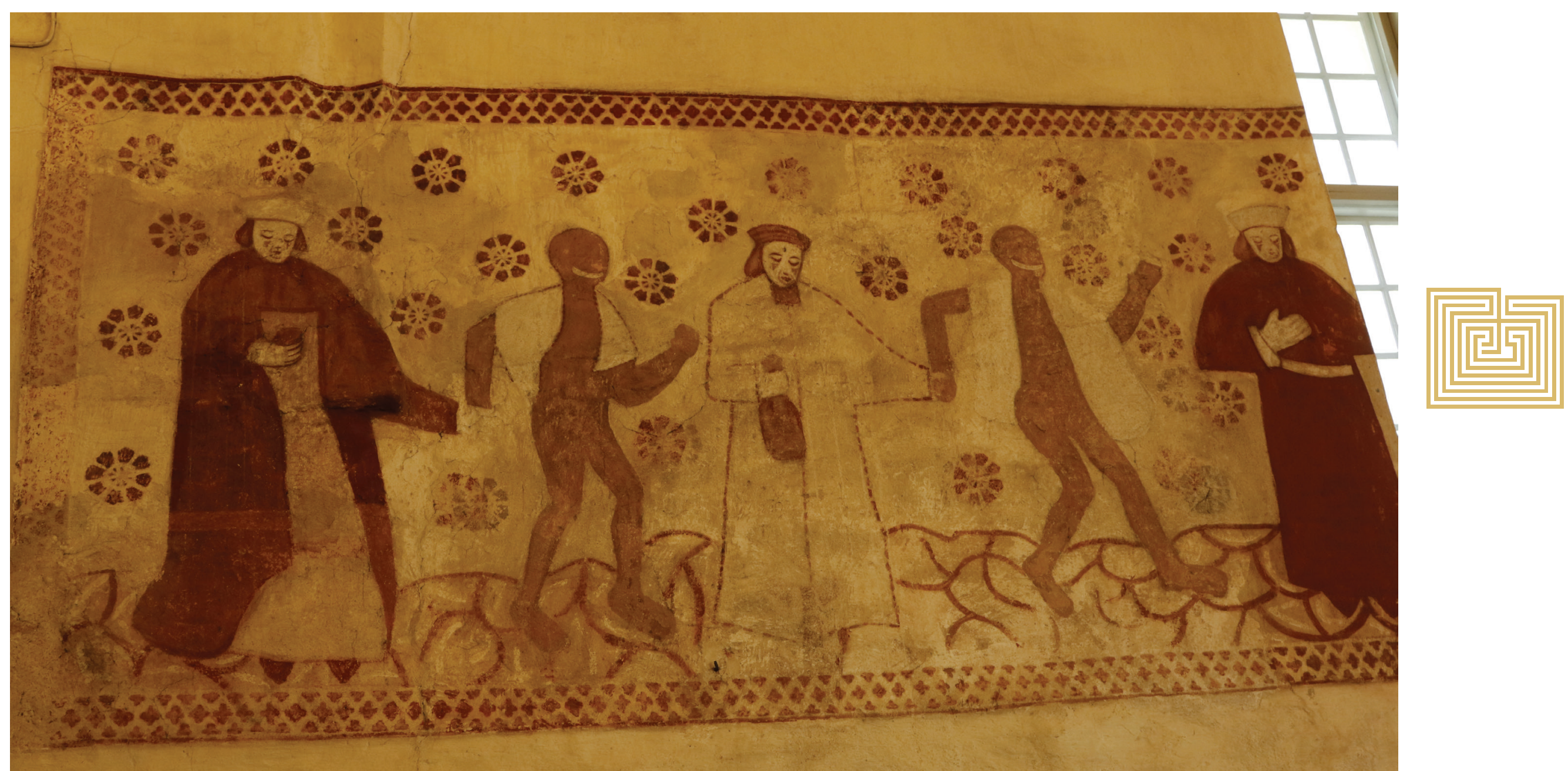

Kuva 2. Kuolemantanssin läntinen osa, noin 1510-luku. Inkoon kirkko. Kuva: Janika Aho 


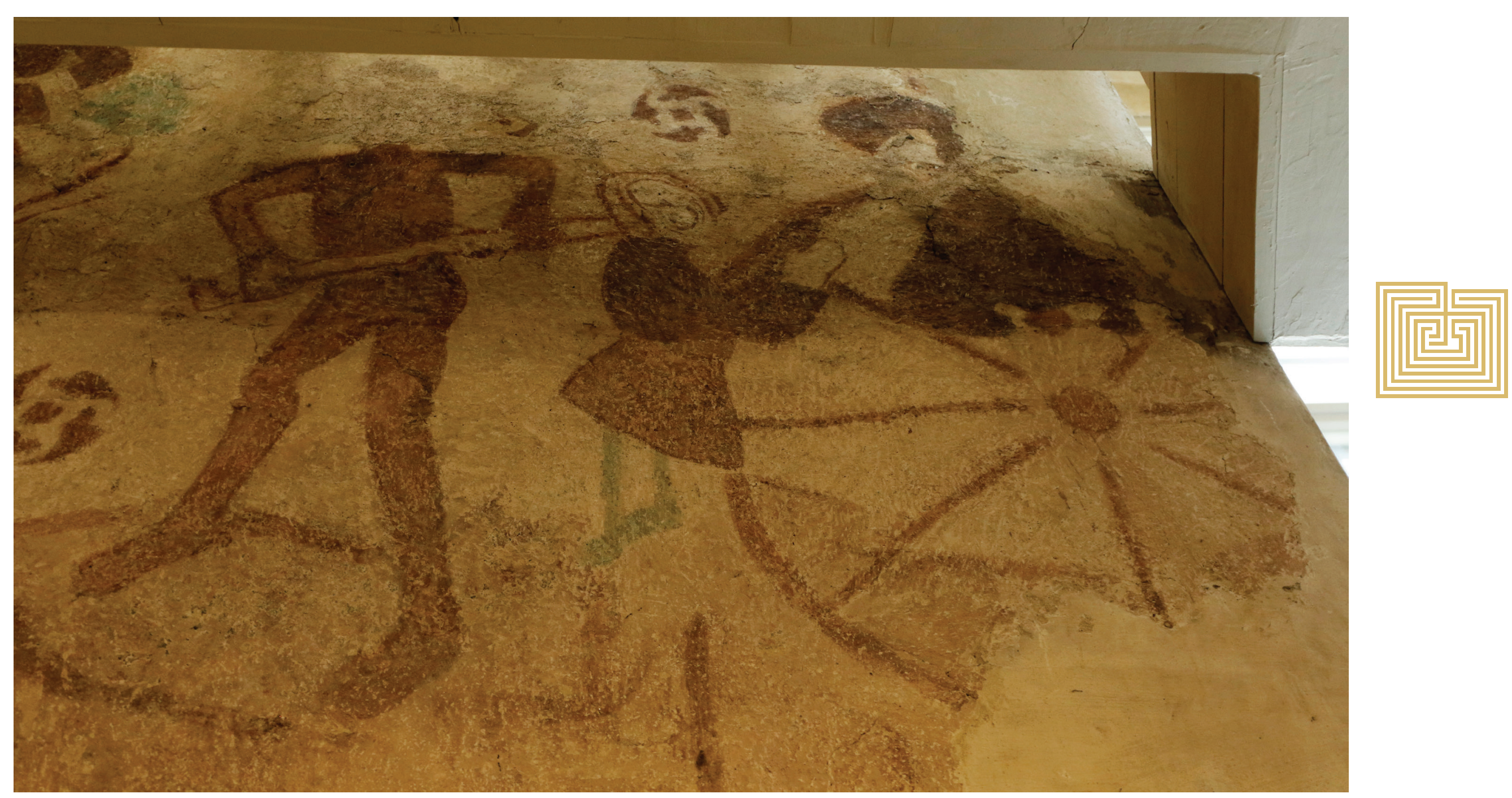

Kuva 3. Elämänpyörä, fragmentaarinen, noin 1510-luku. Inkoon kirkko. Kuva: Janika Aho. 


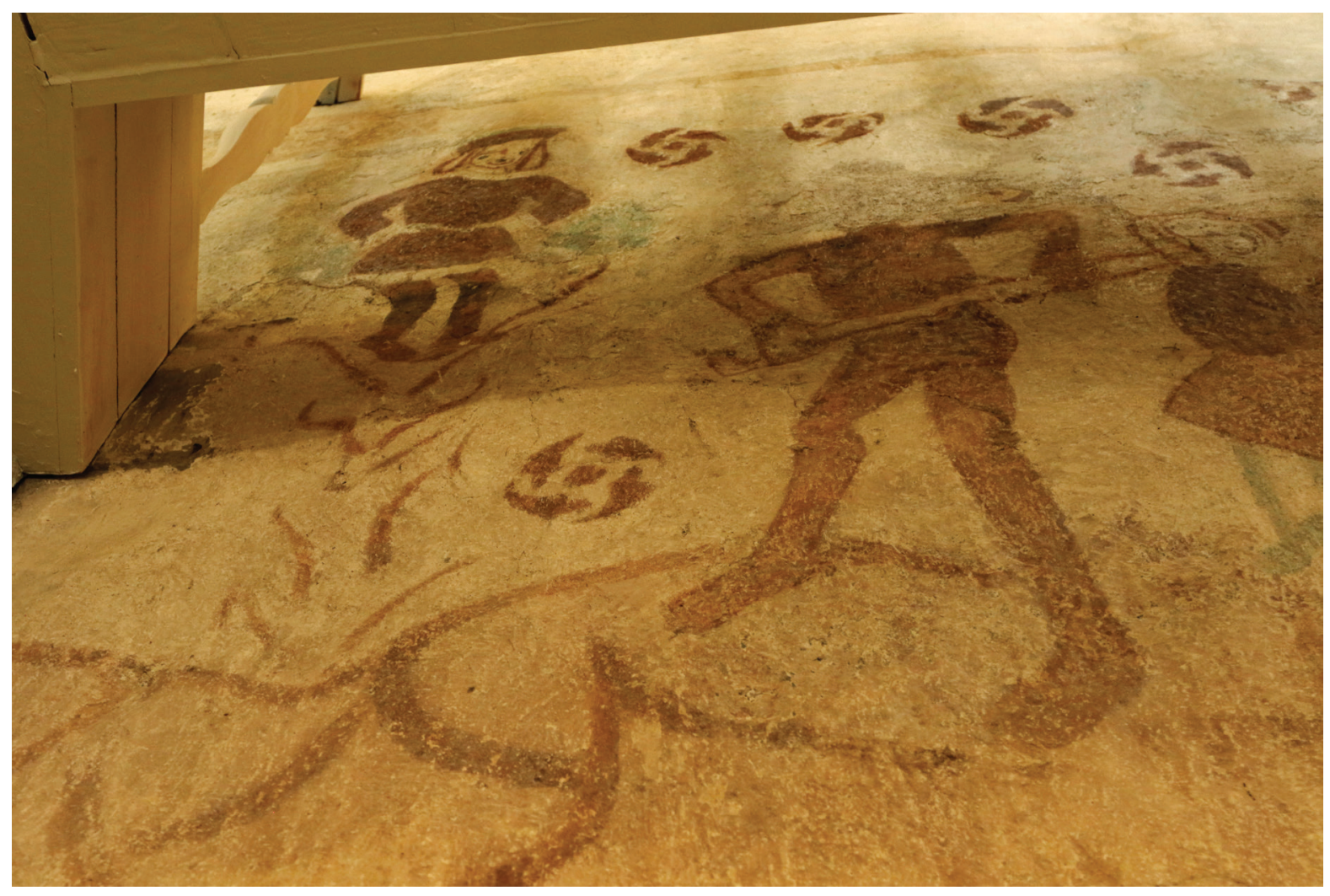

Kuva 4a. Kuolema sahaamassa puuta, noin 1510-luku. Inkoon kirkko. Kuva: Janika Aho.

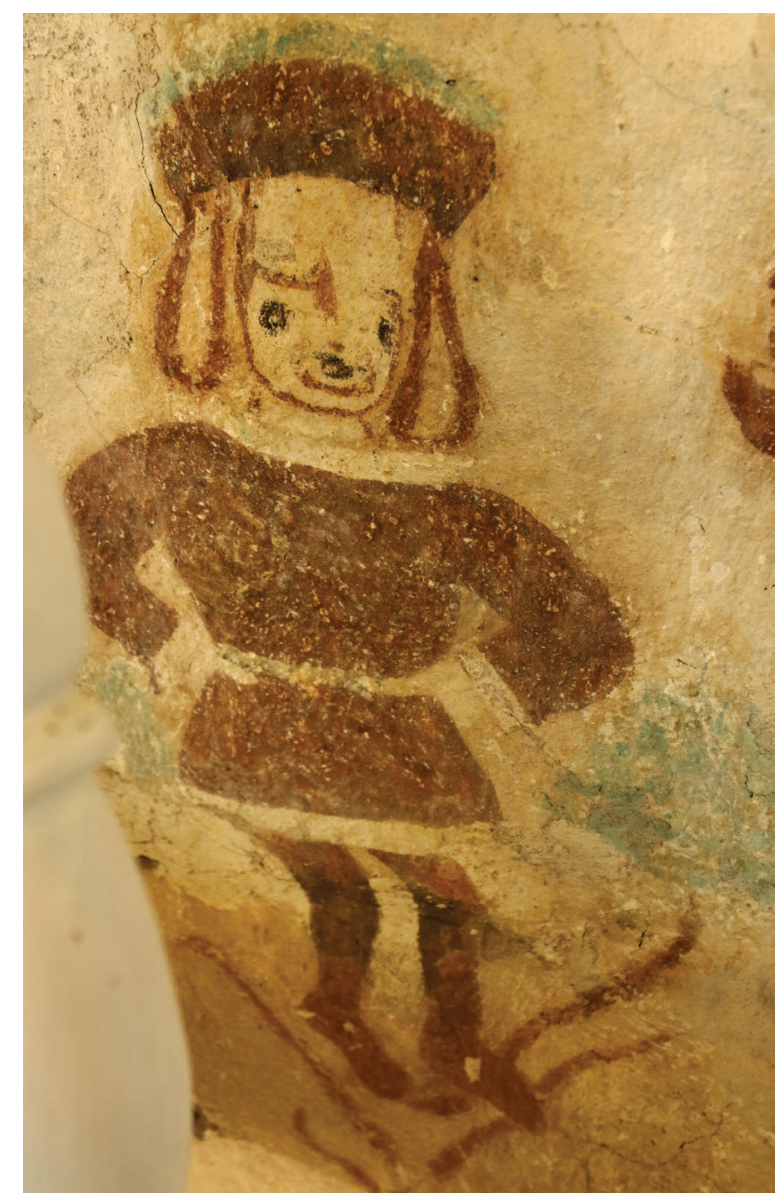

Kuva 4b. Kuolema sahaamassa puuta, yksityiskohta, noin 1510-luku. Inkoon kirkko. Kuva: Janika Aho.

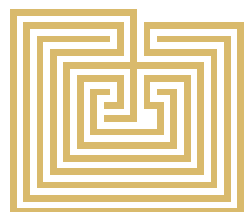


puuta -aihetta, vaan ne käsittelevät Kuolemantanssia omana yksittäisenä aiheenaan ja siten saattavat antaa harhaanjohtavan kuvan aiheen irrallisuudesta ja maalausten muodostaman kokonaisuuden puuttumisesta. ${ }^{7}$ Kuolemantanssia on lisäksi käsitellyt keskiaikaisen kirkkomaalauksen yleisesityksissä Ludvig Wennervirta (1937), Anna Nilsén (1986) sekä Tove Riska (1987). ${ }^{8}$

Tämän artikkelin tarkoitus kaksijakoinen. Ensisijaisesti tarkoituksena on täyttää tutkimuksellinen aukko kahden edellä mainitun memento mori -aiheen suhteen. Toissijaisesti tarkoituksena on päivittää Inkoon Kuolemantanssiin liittyvää tutkimusta ja tuoda se esiin osana näiden kolmen memento mori -kuvan muodostamaa kokonaisuutta ja niiden merkitysten aatteellista kontekstia. Tutkimukseni menetelmä on ikonografinen analyysi. ${ }^{9}$ Selostan aluksi lyhyesti käsillä olevien kuva-aiheiden sijoittumista kirkkotilaan ja suhdetta muuhun maalauskokonaisuuteen. Tämän jälkeen kontekstualisoin käsillä olevien kuva-aiheiden moraalista ja teologista sisältöä suhteessa laajempaan memento mori -ilmiöön ja myöhäiskeskiaikaiseen käsitykseen kuolemasta sekä hyvästä elämästä. Sitten esittelen Kuolema sahaamassa puuta -aiheen ja Elämänpyörän ja vertailen niitä Ruotsin alueella säilyneisiin vastaaviin kuva-aiheisiin. Tässä hyödynnän erityisesti Pia Melinin memento mori -aiheita Albertus Pictorin työhuoneen maalauksissa käsittelevää väitöskirjaa (2007). Käyn läpi Kuolemantanssi -aiheen eri ilmenemismuotoja ja Inkoon Kuolemantanssia tätä taustaa vasten sekä analysoin kaikkien näiden kolmen aiheen muodostamaa memento mori -kokonaisuutta Inkoossa.

\section{Inkoon kirkon kalkkimaalaukset}

Inkoon kirkko on kaksilaivainen, neljän holvivälin mittainen rakennus. Se on rakennettu vuosien 1430-1510 välillä kolmessa eri vaiheessa. ${ }^{10}$ Sen keskiaikaisista, lähes koko sisätilan kattaneista maalauksista ovat nähtävillä ainoastaan kuorin fragmentaariset maalaukset, Kuolemantanssi sekä pohjoisseinän sakastin oven vieressä oleva pieni Pyhää Yrjänää ja lohikäärmettä esittävä kuva. Inkoon maalaukset ovat samaa maalausryhmää Espoon ja Siuntion maalausten kanssa. ${ }^{11}$ Näiden kaikkien kuva-aiheista ja kasviornamentiikasta sekä henkilöhahmojen kuvauksesta voi löytää yhteneväisyyksiä, jotka tukevat ajatusta ainakin osittain sa- moista tekijöistä. ${ }^{12}$ Erityisen silmiinpistävää näissä kaikissa maalauskokonaisuuksissa on henkilöhahmojen suljetut silmät. Syynä tälle on todennäköisesti käytettyjen mallikuvien esimerkki. ${ }^{13}$ Maalauskokonaisuudet eroavat kuitenkin jonkin verran toisistaan aiheiltaan. Inkoon maalausten yhteydessä ei ole löytynyt jäänteitä Vanhan testamentin kohtauksia kuvittavista aiheista, kun taas Espoossa ja Siuntiossa kuvaohjelman rakenne on perustunut Vanhan ja Uuden testamentin typologioihin.

Inkoon maalaukset on ajoitettu noin vuoteen 1510 sillä perusteella, että vuonna 1509 tanskalaiset hävittivät Inkoon kirkkoa ja sen jälkeen kirkossa toteutettiin korjaustöitä ja laajennus. ${ }^{14}$ Ajoitus saattaa olla myöhäisempikin, aina 1520-luvulle ja reformaatioon asti, sillä maalauskokonaisuus on saatettu teettää joitakin vuosia korjaustöiden jälkeenkin. ${ }^{15}$

Inkoon kirkon maalaukset löydettiin ja paljastettiin esiin kalkkikerroksen alta vuonna 1894 Inkoon seurakunnan aloitteesta. Emil Nervander kirjoitti Arkeologiselle komissiolle raportin rappauksen alta paljastuneista maalauksista ja ne myös dokumentoitiin kalkeerauksin ja akvarellein Armas Lindgrenin toimesta. ${ }^{16}$ Vuonna 1896 kaikista fragmen- 
taarisimmat maalaukset päätettiin peittää uudestaan ja vain kuorin maalaukset ja Kuolemantanssi jätettiin näkyviin ja restauroitiin ajan tapaan voimakkaasti alkuperäisten kuvien päälle maalaten.

Kuorissa tänäkin päivänä näkyvissä olevien Jeesuksen ja Neitsyt Marian elämänvaiheita sekä evankelistoja esittävien aiheiden lisäksi kirkossa on ainakin ollut eri pyhimysten kuvia sekä kasviaiheisia ornamentteja toisen ja kolmannen holvirivin holvivaipoissa sekä länsiseinässä Pyhän Yrjänän legendaa kuvaava aihe. ${ }^{17}$ Nykyäänkin nähtävillä oleva pohjoisseinän Yrjänä -aihe on todennäköisesti eri maalarin mahdollisesti eri aikaan tekemä, sillä länsipäädyssä ollut suurikokoinen Yrjänä -kuva on yksityiskohdiltaan hyvin erilainen tämän pienikokoisen Yrjänä -kuvan kanssa. Länsipäädyn Yrjänä seisoo ajanmukaisessa ja yksityiskohtaisesti kuvatussa sotisovassaan lippu ja miekka kädessä, kun taas pohjoisseinän yksinkertaisemmin maalattu, pitkään jakkuun pukeutunut Yrjänä surmaa miekallaan maassa makaavaa lohikäärmettä. Yrjänä-kuvien perusteella on hyvin todennäköistä, että kirkossa on toiminut kaksi eri maalariryhmää kahtena eri aikana.

Kirkon runkohuoneen keskiosasta tarkas- teltuna Kuolemantanssi kulkee pohjoisseinällä kuvanauhan sisällä, jonka alareunassa on kuvattu pyörein viivakaarin maanpinta, jolla kulkueen hahmot kävelevät. Kuolemantanssin katkaisee keskeltä vuonna 1820 tehty ikkuna. ${ }^{18}$ Ikkunan itäpuolella sijaitsee kolme paria tanssijoita ja sen länsipuolella toiset kolme. Toiseksi viimeisin pari on edelleen lehterin rakenteiden alla ja viimeisestä parista näkyvät lehterin alta vain alaraajat (Kuva 5)

Kuolemantanssin länsipuolella, osittain lehterin peittämänä on ensin Elämänpyörä suuren pyörän muodossa ja sen vasemmalla puolella, kaikista läntisimpänä Kuolema sahaamassa puuta -aihe. Vuosina 1987-1988 tehdyistä lehterin muutostöistä huolimatta kuva-aiheita täytyy edelleen tutkailla osittain lehterin ja seinän väliin kurkistelemalla ja osittain kiipeämällä lehterille ja tarkastelemalla maalausta lehterin lattiarajan ja kirkon seinän väliin avatusta aukosta. Molemmat kuva-aiheet ovat yläosastaan täysin pois kuluneita ja rajoittuvat reunoiltaan lehterin tukirakenteisiin.

Kuolemantanssin maanpinta jatkuu luoteisnurkkaa kohden yhtenäisenä, joskin se on restauroitu vain lehteriin asti. Lehterin alla maalaus on fragmentaarinen. Näin Kuolema sahaamassa puuta ja Elämänpyörä lepäävät samalla kuvioidulla maanpinnalla kuin Kuolemantanssi ja muodostavat siten yhtenäisen jatkumon ja kokijalle yhtenäisen kuvakokemuksen. Lukusuunnan ollessa vasemmalta oikealle ne sijoittuvat sen alkupäähän (Kuva 6). Kuolemantanssin kohdalla kuvanauhassa on sablonilla tehty reunus, eräänlainen kehys, joka kuitenkin päättyy lehterin kohdalle. Siitä ei ole jälkiä restauroimattomalla kuva-alueella, eli kyseinen kehys on tehty 1890-luvun restauroinnin aikana korostamaan Kuolemantanssia omana aiheenaan. Keskiaikainen kuvanauha on kuitenkin yhtenäinen jatkumo ja kuvioitu maanpinta toimii sen ainoana rajauksena.

Näiden kolmen kuvan muodostama memento mori -kokonaisuus on ollut selkeästi havaittavissa kirkon eteläisestä pääsisäänkäynnistä kirkkotilaan tultaessa ja näkyvällä paikalla vastassa myös keskiaikaisesta läntisestä sisäänkäynnistä sisään astunutta kirkossakävijää.

\section{Memento mori myöhäiskeskiajalla}

Memento mori (lat.),"muista kuolevaisuutesi", on latinankielinen sanonta, joka kuvaa 


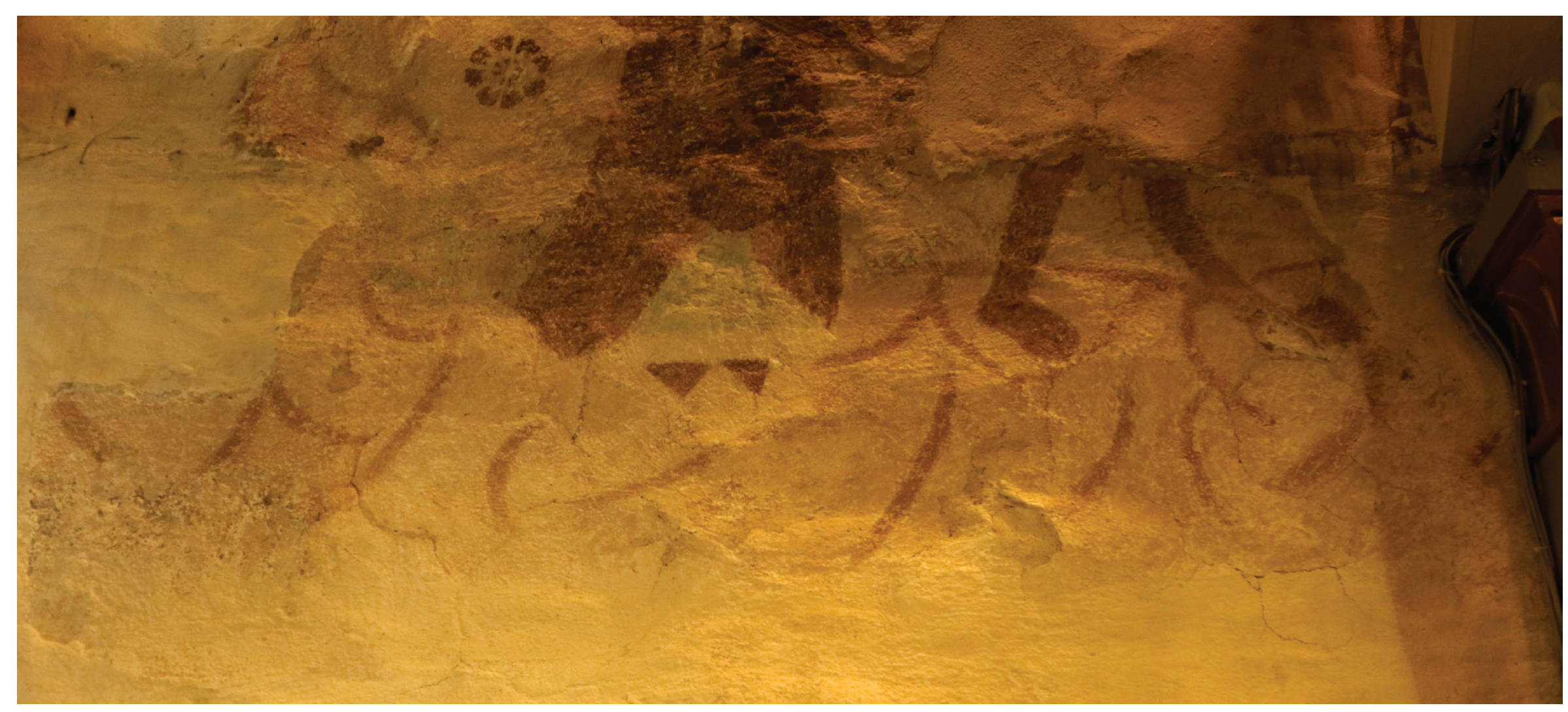

Kuva 5. Kuolemantanssi, yksityiskohta nykyisen lehterin alla. noin 1510-luku. Inkoon kirkko. Kuva: Janika Aho. 


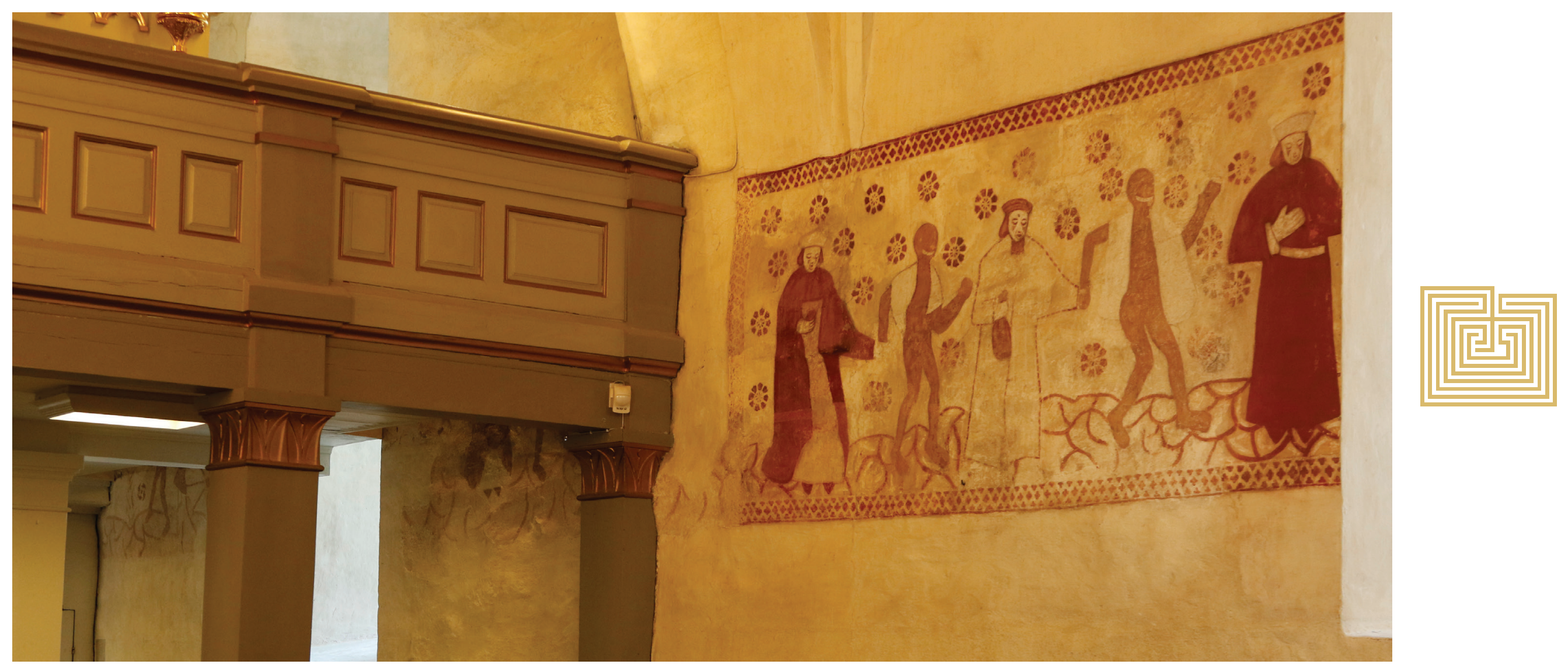

Kuva 6. Kuolemantanssi, noin 1510-luku. Inkoon kirkko. Kuva: Janika Aho. 
oleellisesti myöhäiskeskiaikaista kuoleman kulttuuria. Kuolema oli oleellisesti läsnä inmisten arjessa ja sekä omaan että läheisten kuolemaan liittyvät käytännölliset sekä hengelliset asiat huolettivat aikalaisia. ${ }^{19}$ Myöhäiskeskiajalla yksilöllisen uskonnonharjoituksen korostuminen, Kristuksen kärsimyksiin samaistuminen ja viimeisen tuomion odotus sekä hyvään kristilliseen kuolemaan valmistautuminen toivat esiin elämän haurauden ja kuoleman väistämättömyyden teemoja niin kirjallisuudessa kuin kuvataiteessakin. Memento mori -tematiikka on läsnä niin Viimeistä tuomiota kuvaavissa kirkkojen seinämaalauksissa, hyvää kuolemaa kuvaavassa ars moriendi -kirjallisuudessa kuin allegorisissa kuvauksissa elävien ja kuolleiden kohtaamisesta. ${ }^{20}$ Memento mori muistuttaa kokijaansa inmiselämän lyhyydestä ja aineellisen elämän synneistä, kuten ylpeydestä, himosta tai ahneudesta. Kuoleman vääjäämättömyyden pohdiskelu voidaan nähdä laajemmin myös osana maailmankuvan rakentumista ja sen tutkailua, contemptus mundia. ${ }^{21}$

Kuolemattoman sielun hyvinvointi nousi teologiassa keskiöön kiirastuliopin virallistamisen myötä 1200-luvulta alkaen. Täten yksilön lopullisen kohtalon uskottiin tapahtu- van vasta tuonpuoleisessa, jossa hän saattoi kärsiä synneistään ja siten puhdistautua. Yksilö saattoi vaikuttaa omaan aikaansa kiirastulessa elämällä elämänsä hyvin. ${ }^{22}$ Moraalin ja hyvän elämän pohdinta olivat kuitenkin keskeisiä asioita muuallakin kuin vain korkeasti oppineiden teologien kirjoituksissa. Myöhäiskeskiajan muutokset kuten kaupungistuminen ja kaupunkilaisammattien syntyminen johtivat yhteiskunnan rakenteen murrokseen ja tarpeeseen pohtia yksilön asemaa yhteisönsä jäsenenä. Tällöin korostui myös yksilön moraalinen vastuu yhteisöään kohtaan. ${ }^{23}$

Syntien ja niiden välttämisen pohtiminen ja opettaminen oli oleellinen osa exemplum -traditiota, joissa opettavaisten tarinoiden (exempla) avulla välitettiin moraalisia sanomia ja varoitettiin synnistä erilaisia vertauskuvia ja hahmojen arkkityyppejä hyödyntäen. ${ }^{24}$ Memento mori -kuvissa kuvan sisältö välittyy samaan tapaan arkkityyppien ja vertauskuvien kautta yksilön kohdatessa fyysisen kuoleman personifikaation. Näiden kohtaamisten herättämä vaikutus perustuu vastakkainasetteluun: Kuolemasta muistuttamalla ne kehottavat elämään hyvin ja oikein.
Kuolema-hahmo, eräänlainen elävä kuollut, liittyy myös ruumiiseen sekä sen prosesseja ja rajoja kuolemassa tutkailevaan makaaberin tendenssiin taiteessa. Myöhäiskeskiajalla makaaberin kuvan suosio ilmeni esimerkiksi kaksikerroksisten transi -hautamonumenttien rakentamisena ja kuolemantanssin yhteydessä erilaisten mätänemisen prosesseja esittävien ruumiiden kuvaamisena. ${ }^{25}$ Makaaberin taiteen ja memento mori -aiheiden alkuperä on sekä kirjallisena että kuvallisena liitetty aiemmin tutkimuksessa 1340-luvulla alkaneisiin ruttoepidemioihin eli niin sanottuun mustaan surmaan. Uuden tutkimuksen valossa näiden merkitykset kuitenkin resonoivat ennen kaikkea myöhäiskeskiaikaisen, yksilöllistä sielun hyvinvointia ja inmisen maallisen elämän rajallisuutta korostavan aatemaailman kanssa. Lisäksi ne kietoutuvat ruumiillisuutta ja sen rajoja tutkailevan myöhäiskeskiaikaisen aatemaailman kanssa. ${ }^{26}$ Tällöin esimerkiksi Kristuksen ruumiin kultti voidaan nähdä yhteydessä ruumiillisuutta tutkailevaan makaaberiin kuvaan. ${ }^{27}$ Makaaberi kiinnostus ruumista ja kuolemaa kohtaan on ymmärrettävissä ylipäätään yksilön elämän ja kuoleman korostumisen kontekstissa - ruumis ja sen rajat ovat myös yksilön rajoja. 
Memento mori -kuvat ovat hyvän elämän ja sielun hyvinvoinnin kontemplaatioon kehottavina kuvina lähellä moraliteettikuvien lajia: Suomen alueella säilyneitä moraliteettiaiheita ovat muun muassa Varkain lypsy, Kirkossa juoruaminen sekä Kenkä-Ella, joiden esikuvia voidaan löytää yleiseurooppalaisesta tarinaperinteestä. ${ }^{28}$ Moraliteettikuvissa on läsnä usein paholainen ja niiden vaikutus perustuu inmisen ja paholaisen vuorovaikutukseen synnillisen teon toteuttamisessa. Moraliteettikuvat ja memento mori -kuvat esiintyvät usein lähekkäin kirkkojen seinämaalauksissa. Esimerkiksi Ruotsin Upplannissa sijaitsevien Husby-Sjutolftin ja Härnevin kirkoissa elämänpyörä, kuolema sahaamassa puuta ja kenkä-Ella on sijoitettu kirkon asehuoneeseen ja Kungs-Husbyn kirkon asehuoneessa puuta sahaava kuolema on sijoitettu juoruamisesta varoittavan moraliteettikuvan viereen. ${ }^{29}$ Tässä pienessä eteistilassa ne ovat olleet lähellä katsojaa ja myös tiiviissä vuorovaikutuksessa keskenään, näkyvillä ja katsojan silmien tasalla. Kirkossa juoruamisen moraliteetti on taas yhdistetty kuolemantanssiin ainakin Ranskan Meslay-le-Grenetin kirkossa (maalaukset noin 1500) ja elämänpyörä esiintyy yhdessä kuolemantanssin kanssa ainakin Kroatian Beramin Pyhän Marian kirkossa (Vincent Kastavin maalaukset 1474). ${ }^{30}$ Moraliteetti- ja memento mori -kuvien yhteen asettaminen temaattiseksi kokonaisuudeksi on siis jossakin määrin yleiseurooppalainen perinne.

Inkoon kirkossa on sijainnut ainakin yksi moraliteettikuva. Myös Espoosta ja Siuntiosta länsisisäänkäynnin yläpuolelta löytyvä Kenkä-Ella -aihe on ollut Inkoossa, mutta se on peitetty vuonna $1896 .{ }^{31}$ Kenkä-Ella -aihe, jossa piru ojentaa pitkän seipään nokassa kengät naiselle, perustuu tarinaan viekkaasta ja ahneesta naisesta, joka lupaa erottaa erään avioparin vastineeksi uusista kengistä. Näin tapahtuukin ja paholainen ojentaa Ellalle kengät seipään nokassa matkan päästä kunnioituksen ja pelon osoituksena. ${ }^{32}$ Inkoossa tämä aihe on sijainnut pohjoisseinällä, Elämänpyörän ja Kuolema sahaamassa puuta -aiheen yläpuolella tai vieressä niin, että sen alaosa on peittynyt vuonna 1820 rakennetun lehterin alle. ${ }^{33}$ Inkoon Kuolemantanssin yhteydessä on siten näyttäytynyt keskiaikaiselle katsojalle paitsi elämän ja kohtalon arvaamattomuudesta muistuttava Elämänpyörä ja ylpeyden synnistä varoittava Kuolema sahaamassa puuta, myös ahneudesta varoittava tarina naisesta ja paholaisesta.

Memento mori -kuvien, kuten moraliteettikuvienkin, vaikutus on perustunut niiden sisältämiin tarinoihin. Kuvien sisältö on ollut useimmille katsojille tuttu entuudestaan ja kuva on siten muistuttanut tarinasta ja sen opetuksesta. ${ }^{34}$ Näin puussa seisoskeleva nuorukainen tai pirulta uudet kengät vastaanottava nainen toimi kelle tahansa katsojalle allegoriana ja moraalisena muistutuksena materiaan kiintymisestä ja maallisten asioiden turhasta haalimisesta. Kuvat voidaan lukea varoittavina ja parannukseen kehottavina autoritäärisinä tai opettavaisina esimerkkeinä, mutta niillä on toisaalta voinut olla myös hyvän elämän pohtimiseen ja vaalimiseen liittyvä ulottuvuus yksilön elämässä. Omalta osaltaan ne ovat myös vahvistaneet yhteisöllisyyttä; Moraalin vaaliminen ja hyvä kristillinen elämä olivat myös yksilön yhteisöllisiä velvoitteita. ${ }^{35}$

\section{Elämänpyörä ja kuolema sahaamassa puuta}

Inkoossa kuvanauhan aloittaa aihe Kuolema sahaamassa puuta. Aiheen länsipuolella on kenties ollut vielä jokin muu memento mori 
-kokonaisuuteen liittyvä aihe, mutta lehteri peittää koko alueen aiheen länsipuolella. Aiheessa erottuu aaltoilevalla viivalla muotoiltu puu, jonka latvuksessa istuu henkilö tiukoissa housuissa ja pussittavassa, lyhyessä jakussa. Hahmo on tunnistettavissa nuoreksi, tyylikkäästi pukeutuneeksi mieheksi, jonka pitkät hiukset ja korkea päähine muiden eleganttien vaatteiden ohella viittaavat aateliseen. Nuorukainen on kuvattu viitteellisesti istuvassa asennossa. Hänenkin silmänsä ovat muiden Inkoon henkilöhahmojen tapaan suljetut ja tummat läikät poskilla viittaavat alun perin punaisella maalattuihin poskipäihin.

Puun oikealla puolella tummasävyinen, ruumista tai luurankoa muistuttava hahmo pitelee pitkävartista työkalua. Hahmo on kuoleman personifikaatio, joka pitkävartisella sahalla sahaa puuta poikki nuorukaisen alta. Inkoossa työkalua ei ole mahdollista varmasti tulkita juuri sahaksi, vaan se voi olla myös jokin muu maataloustyökalu, esimerkiksi hyvin pienilapainen lapio. Tässä on mahdollista, että maalari on noudattanut virheellisesti mallikuvaansa tai että malalikuvaa ei ole ollut laisinkaan, vaan kuva-aiheen toteutus on perustunut ulkomuistiin tai suulliseen kertomukseen.
Kuolema sahaamassa puuta on elämän ja kuoleman arvaamattomuutta kuvaava aihe. Siinä tyypillisesti muodinmukaisesti pukeutunut nuori mies istuu puun latvassa (Kuva 7). Kuten Pia Melin on todennut, tämä hahmo edustaa itsekkyyden, turhamaisuuden ja itseriittoisuuden ominaisuuksia, jota viestittää erityisesti kalliit vaatteet ja lanteille nostetut käsivarret. ${ }^{36}$ Puun vierellä kuolema-hahmo joko luurankomaisena tai makaaberina ruumiina sahaa puuta poikki. Tästä kuvatyypistä on lukuisia eri variaatioita, joskus se esiintyy myös ilman kuoleman personifikaatiota. ${ }^{37}$ Kuolema sahaamassa puuta löytyy Ruotsissa ainakin kahdeksasta keskiaikaisesta seinämaalausten kokonaisuudesta ja useimmiten se on sijoitettu asehuoneeseen. ${ }^{38}$

Aiheelle ei löydy suoraa esikuvaa kirjallisuudesta tai mallikuvista, vaan se vaikuttaa kehittyneen usean eri lähteen vaikutuksesta. Yksi mahdollinen tarinan alkuperä on Johannes Damaskoslaisen 700-luvulla ylös kirjaama Barlaamin ja Josefatin kertomus, jossa erakko Barlaam käännyttää Josafatin kristinuskoon kymmenen vertauskuvan avulla. Yksi näistä on tarina nuorukaisesta, jonka yksisarvinen jahtaa puuhun ja siellä turvassa ollessaan ja puun mahlasta nauttiessaan

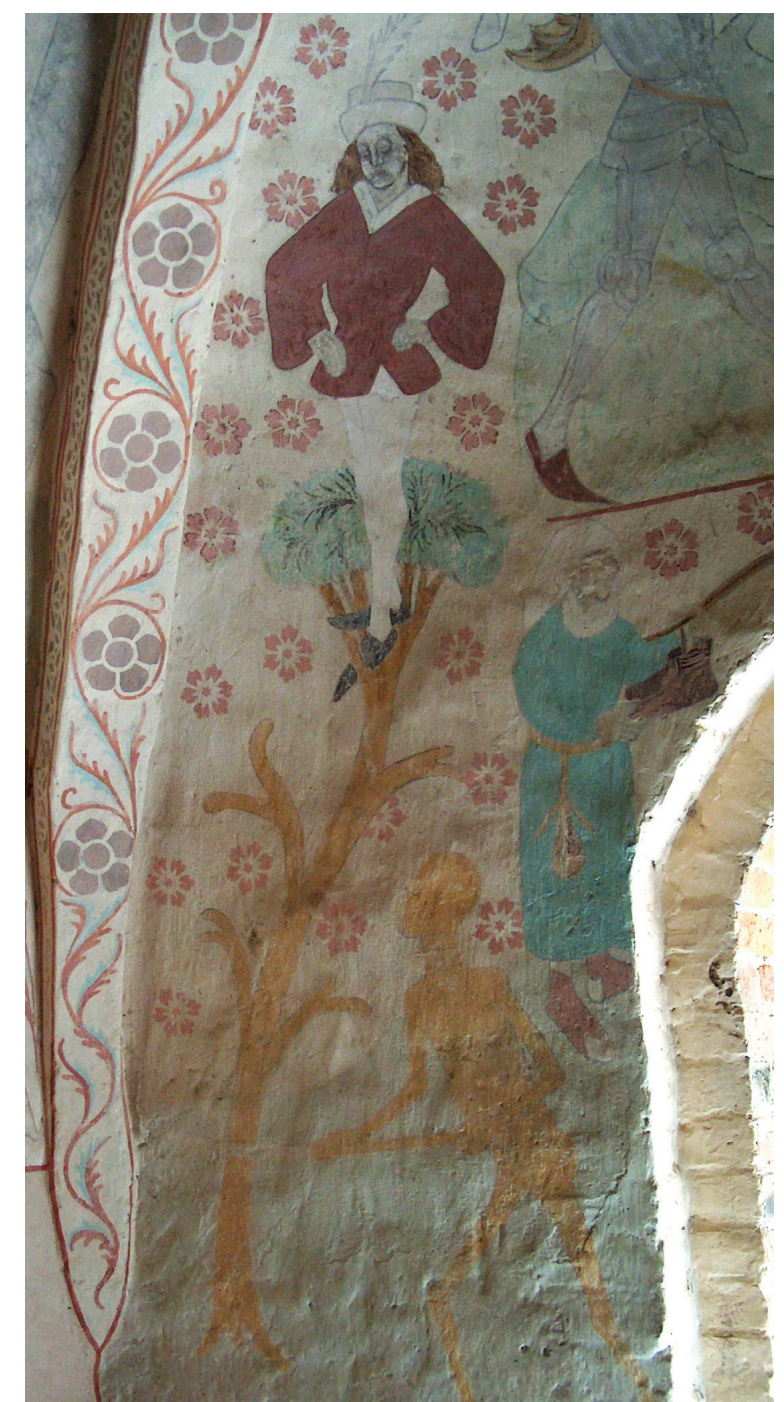

Kuva 7. Albertus Pictor, Kuolema sahaamassa puuta, noin 1470-1480-luvut. Husby-Sjutoftin kirkko, Upplanti. Kuva: Pia Me- 
ei huomaa juuria nakertavia hiiriä. ${ }^{39}$ Barlaam kuvailee tarinan opetusta näin:

"Oksa, josta hän piteli kiinni, tarkoittaa hänen elämäänsä. Valkea ja musta hiiri ovat päivä ja yö, jotka aina jäytävät miehen elämää ja kiiruhtavat kohti kuolemaa --- Hunajapisaroilla tarkoitetaan maailman riemuja ja ruumiin nautintoja, joilla tuo kavaltaja pettää ystävänsä niin, että he unohtavat sielunsa ahdingon eivätkä näe omaa autuuttaan."

Ajan kuluminen, lähestyvä kuolema ja aineellisen katovaisuus ovat täten legendan oleellisia sisältöjä.

Maallinen tuhlaavaisuus ja elämän rajallisuus toistuvat myös Tierpin kirkon Kuolema sahaamassa puuta -maalauksessa (noin 1470), jossa on säilynyt nuorukaisen ja kuoleman välinen keskustelu inskriptiona. Kuolema vastaa maallisesta omaisuudesta ilakoivalle nuorukaiselle: "Du bre ut penningar ok guld Du tenker intet paa dödsens stund" eli "Sinä kulutat rahaa ja kultaa, etkä ajattele kuoleman hetkeä". ${ }^{41}$

Edettäessä oikealle eli itään on Inkoon kirkossa vuorossa Elämänpyörä -aihe. Siinä rattaan pyörää muistuttavan valtavan pyörän kyydissä istuu myös tyylikkäästi tiukkoihin housuihin ja suippokenkiin pukeutunut mieshahmo, joka on matkalla pyö- rän lakipisteeseen. Pyörän huipulla olevan hahmon ulkoasusta on erotettavissa korkea päähine, joka muistuttaa Kuolemantanssin kuningashahmon päähinettä. Pyörän oikea puoli on kokonaan tuhoutunut ikkuna-aukon tieltä ja sen alaosa on kulunut pois. Vertailemalla muihin Elämänpyörä -aiheisiin (Kuva 8 ja Kuva 9) voidaan sanoa, että pyörässä on ollut vielä ainakin kaksi muuta henkilöä - yksi pyörän ylimmällä kohdalla, yksi putoamaisillaan oikealla puolella ja sekä maassa vielä ruumisliinalla peitetty kalmo.

Elämän- tai Onnenpyörä, Rota Fortunae, on yhdessä Fortuna-jumalattaren hahmon kanssa antiikista periytyvä elämän ja kohtalon vertauskuva. Fortuna-hahmon yleisyys keskiajan kirjallisuudessa ja kuvissa juontuu osaltaan Boethiuksen De consolatione philosopiae (n. 524) --teoksen suuren suosioon keskiajalla. Teoksessa Fortunalla on merkittävä rooli elämän epävarmuuden allegoriana. $^{42}$ Fortuna pyörineen on keskeinen hahmo myös esimerkiksi käsikirjoituskokoelma Carmina Buranassa (n. 1230luku) ja pohdinnat moraalista, onnesta ja vapaasta tahdosta voidaan ylipäätään nähdä merkittävänä osana keskiajan kulttuurin maallisten asioiden pohdintaa, contempus mundia. ${ }^{43}$ Myöhäiskeskiajalla Fortunan kuvaaminen muuttui muotoon, jossa Fortuna pyörittää pyörää sen sijaan, että esimerkiksi seisoisi sen päällä. ${ }^{44}$ Tämä kuvatyyppi koostuu isosta pyörästä tai rattaasta, jolla neljästä kahteentoista mieshahmoa pyörivät. Yksi hahmoista makaa pyörän seesteisesti haudassaan käärinliinaan puettuna ruumiina. Kuva-aiheeseen saattaa kuulua myös kuoleman hahmo pyörän oikealla puolella kiskaisemassa kolmatta matkustavaa miestä alas pyörän kyydistä. Inkoossakin on saattanut ollut kuolema-hahmo vielä pyörän itäpuolella.

Elämänpyörä -aiheessa on kuvan lisäksi usein myös selittävät, latinan kielen aikamuodoilla leikittelevät tekstit: nuori mies matkalla pyörän lakipisteeseen on varustettu tekstillä regnabo (tulen hallitsemaan), pyörän ylimmällä kohdalla istuva, usein kruunupäisen, keski-ikäisen miehen teksti on regno (hallitsen), pyörän kyydistä tippuvan, iäkkään miehen selittävänä tekstinä puolestaan on regnavi (hallitsin) ja maassa makaavan ruumiin vieressä lukee sum sine regno (olen ilman valtaa.) Tällainen tekstein varustettu elämänpyörä löytyy myös Carmina Buranan ensilehdeltä. ${ }^{45}$ 


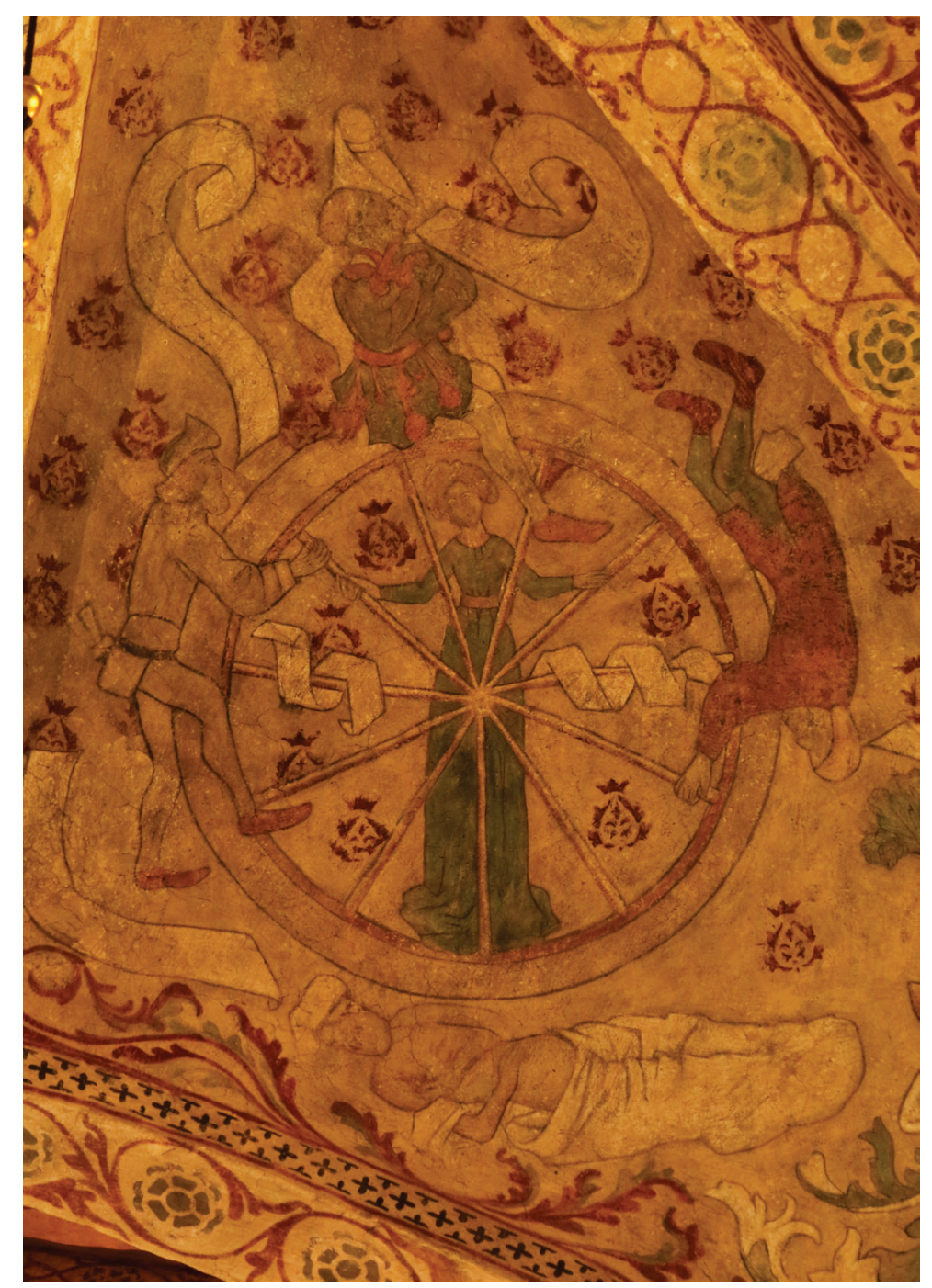

Kuva 8. Peter Målare (työh.), Elämänpyörä, noin 1460luku. Ösmon kirkko, Upplanti. Kuva: Janika Aho.

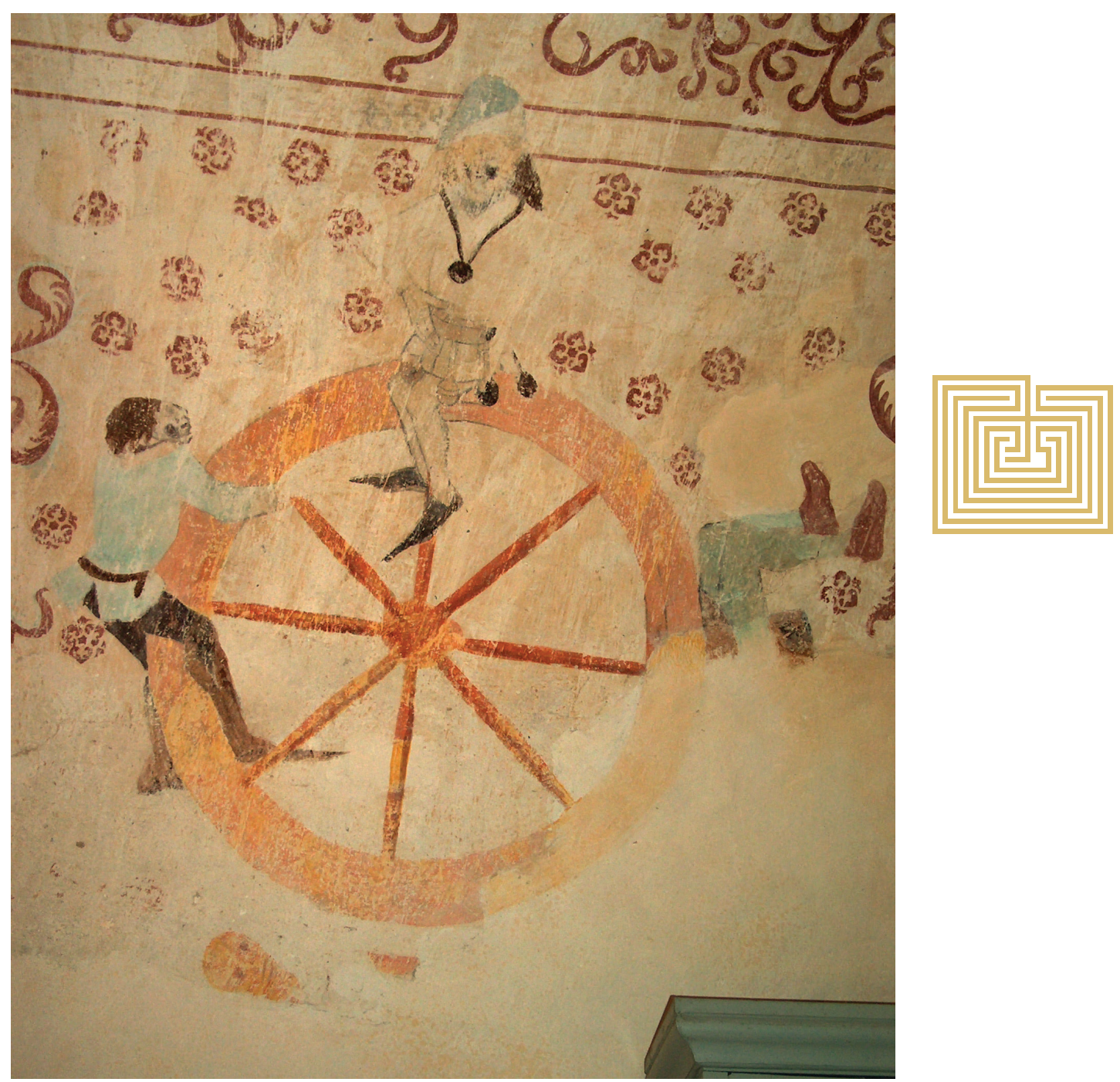

Kuva 9. Albertus Pictor, Elämänpyörä, noin 1470-1480-luvut. Österundan kirkko, Upplanti. Kuva: Pia Melin. 
Inkoon Elämänpyörästä nämä tekstit puuttuvat kokonaan, joka nähdäkseni käy yksiin sen kanssa, että Kuolemantanssiinkaan ei ole kuulunut tekstejä. Inkoon Elämänpyörä muistuttaa Upplannin Österundan kirkon vastaavaa aihetta (Kuva 9). Myös siinä tekstit puuttuvat ja pyörä on kuvattu yksinkertaisena kärrynpyöränä, ilman kuolemaa tai Fortuna -hahmoa. Södermanlandissa sijaitsevan Ösmon kirkon Elämänpyörässä (Kuva 8) on nähtävissä nyt tyhjät tekstinauhat, joissa nämä latinankieliset tekstit ovat alun perin sijainneet.

Pyörä-aiheesta on monia eri variaatioita. Elämän rajallisuuden ohella elämänpyörä voi kuvata myös elämän ja kohtalon oikullisuutta, vaihtelevaa menestystä ja kaiken väliaikaisuutta. Joissakin elämänpyörä-aiheissa pyörän pyörivä liike on ainaista, eikä sen kierros ei ole riippuvainen yksilön elinkaaresta - sama henkilö voi elinaikanaan olla vuoroin pyörän huipulla ja sen murskaamana maassa ja toisaalta taas ponnistaa pyörän kyytiin - kyse on siis elämän kiertokulun kuvaamisen sijaan vaihtelevan onnen kuvaamisesta. ${ }^{46}$

Elämänpyörä on paitsi kuvaus inmisen elinkaaresta ja onnesta, myös moraalinen vertauskuva: Se voidaan lukea muistutuksena kohtalon sattumanvaraisuudesta ja jatkuvasta muutoksesta, elämän rajallisuudesta ja siten sen tarkoituksena on varottaa katsojaansa kiintymästä maallisiin asioihin. ${ }^{47}$ Elämänpyörä ja Kuolema sahaamassa puuta ovat Ruotsin alueen maalauksissa usein yhdessä esiintyvä kuvapari. Pyörän ja puun allegoriat esiintyvät monenlaisina eri variaatioina keskiajan kirjallisuudessa ja grafiikantuotteissa, jotka ovat olleet kirkkojen seinämaalausten esikuvia. Puu esiintyy keskiajan kirjallisuudessa Elämänpyörän tavoin myös ihmisen elinkaaren 12 vaiheen kuvaajana, jolloin kyse on allegorisesta Elämänpuusta. ${ }^{48} \mathrm{Puu}$-aiheen eräs versio esiintyy yhdessä Elämänpyörän kanssa ainakin ns. Banderollien Mestarin (aktiivinen 1400-luvun puolivälissä) eräässä grafiikanlehdessä. Tässä Fortunan pyörittämän elämänpyörän vieressä on eri yhteiskuntaluokkien edustajien kansoittama puu, johon luurankohahmoinen kuolema tähtää jousella ja nuolella. ${ }^{49}$ Tämä voidaan tulkita kuolemantanssin kaltaiseksi allegoriaksi äkillisen kuoleman mahdollisuudesta ja inmisten tasa-arvoisuudesta kuoleman edessä.

\section{Kuolemantanssi}

Kuolemantanssi esiintyy kuvissa ensimmäistä kertaa Pariisin Saints-Innocents -hautausmaalla vuonna 1425 ja myöhäiskeskiajalla siitä tuli koko läntisessä kristikunnassa suosittu aihe. ${ }^{50}$ Kuolemantanssissa luurangon tai mätänevän ruumiin muodon saanut kuolema vie tanssiin mukanaan inmishahmoja, joiden puvut kertovat eri sosioekonomisten luokkien edustajista - kulkue etenee vaikutusvaltaan ja yhteiskunnan hierarkiaan perustuvassa järjestyksessä, jossa jokainen inmishahmo muodostaa kuoleman kanssa tanssiparin. ${ }^{51}$ Kirkkojen seinämaalausten lisäksi se esiintyi kirjankuvituksissa ja muissa painotuotteissa sekä julkisissa ulkotiloissa. Se oli käytännöllisesti sovitettavissa eri mittoihin, tarvittaessa lyhennettävissä ja mahdollista sijoittaa erilaisiin arkkitehtonisiin kokonaisuuksiin. ${ }^{52}$ Tavallisesti täysmittainen kuolemantanssi saattoi käsittää lähes 40 tanssiparia. ${ }^{53}$

Kulkueen marssijärjestys perustuu yhteiskunnan hierarkiaan: Ensimmäisenä on esitettynä paavi tai vaihtoehtoisesti kuningas, hänen jälkeensä piispa, edeten hierarkiajärjestyksessä alaspäin aatelisiin, hengellisen säädyn edustajiin, porvareihin, käsityöläisiin

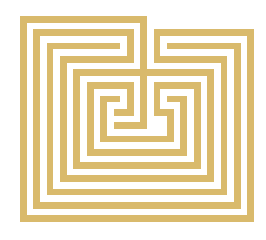


ja talonpoikiin. Joskus kulkueen lopussa on esitettynä nainen tai neito, sekä pieni lapsi kehdossaan, jonka kuolema riistää mukaansa. Jokaisen hahmon sosiaalinen status on selkeästi luettavissa heidän asuistaan, mukanaan kantamista esineistä sekä maalauksen mahdollisesta tekstiosiosta. Paul Binskin mukaan kuolemantanssi toisintaa sosiaalista hierarkiaa ja yksilöiden välisiä valta-asetelmia, samanaikaisesti kuitenkin välittäen viestiä kaikkien inmisten tasa-arvoisuudesta kuoleman edessä. ${ }^{54}$

Inkoossa Kuolemantanssi alkaa hierarkian alkupäästä, Elämänpyörän itäpuolelta. Edgren ja Diel ovat tulkinneet hahmojen järjestystä oikealta vasemmalle lukien, eli hierarkian yläpäästä alaspäin, kulkueen suuntaa vasten lukien. Inkoon maalaus on lukusuuntansa nähden erikoinen, sillä kulkue kulkee vastakkaiseen suuntaan kuin yleisimmin Kuolemantansseissa, jossa sen suunta on vasemmalle ja lukija kulkee oikealle yhteiskunnan hierarkiassa alaspäin edeten. Elina Gertsmanin mukaan kuolemantanssin tulkinta perustuu kokemukseen, jossa teoksen kokija liikkuu kulkuetta vastaan: Tanssikulkue liikkuu kuvassa vasemmalle ja lukija taas etenee lukusuuntaan, vasemmalta oikealle, jolloin teoksen kokija etenee samalla yhteiskunnan hierarkiassa alaspäin, väistämättä kohdaten täten myös "itsensä" jossakin kulkueen kohdassa. ${ }^{55}$ Inkoon Kuolemantanssi etenee juuri päinvastaiseen suuntaan vasemmalta oikealle, eli katsoja nousee yhteiskunnan hierarkiassa koko ajan ylöspäin kulkueen mukana kulkien.

Käyn seuraavassa läpi Inkoon Kuolemantanssin hahmot arvojärjestyksessä, eli aiheen itäisimmästä reunasta aloittaen. Hahmojen identifioinnissa yhdyn Edgrenin ja Dielin tulkintoihin niitä täsmentäen. Ensimmäisenä arvojärjestyksessä kulkueen kärjessä on korkealla päähineellä tai kruunulla varustettu hahmo, kuningas. ${ }^{56}$ Kuningasta johdattava kuolema on kalkittu piiloon ja kulkueen itäpää katkaistu kehyksellä maalausten restauroinnin yhteydessä. ${ }^{57}$ On haasteellista sanoa, onko kulkue alun perin alkanut tästä hahmosta, vai onko kenties alussa ollut vielä yksi tanssipari, mahdollisesti paavi. Paavin puutuminen ei olisi täysin poikkeuksellista, vaan tämä hahmo puuttuu myös esimerkiksi Tanskan Norre Alslevin maalauksesta (Elmelunden työryhmä, noin 1500-1520) (Kuva 10ab). ${ }^{58}$
Kulkueen toinen elävä hahmo on mitran perusteella tunnistettavissa piispaksi. ${ }^{59}$ Tämän jälkeen seuraavalla elävien edustajalla on korkea, kolmesakarainen päähine. Tämän hahmon Edgren on tulkinnut aatelismieheksi ja korkean päähineen sulkakoristeiseksi aatelismiehen hatuksi, Diel taas narrin päähineeksi. ${ }^{60}$ Itse tulkitsen hahmon Edgrenin tavoin aateliseksi, tarkemmin sanottuna rälssin edustajaksi, perustuen hierarkkiseen järjestykseen piispan jälkeen ja erityisesti sulkakoristeiseen päähineeseen: samanlainen löytyy niin Espoon kirkon eteläisellä seinällä kuvatulta kuin Inkoon länsipäädyssä sijainneelta Pyhältä Yrjänältä. ${ }^{61}$ Pyhä Yrjänä kuvataan yleisesti keskiajan taiteessa ritarina tai ratsusotilaana.

Seuraavana järjestyksessä, ikkunan länsipuolella on hahmo, jolla on korkea päähine ja pitkä, vyötetty kaapu. Edgrenin mukaan hahmo olisi varakas maallinen viranhaltija ja Dielin mukaan täsmällisemmin vouti tai muu hallinnollinen virkamies. Yhteiskunnalliseen vastuutehtävään viittaa myös hahmon toinen käsi, jota hän pitelee rintansa päällä osoituksena lupauksesta tai kunnioituksesta. ${ }^{62}$ Viides elävä hahmo pitelee kädessään kukkaroa tai pientä säkkiä ja päässään hänellä 

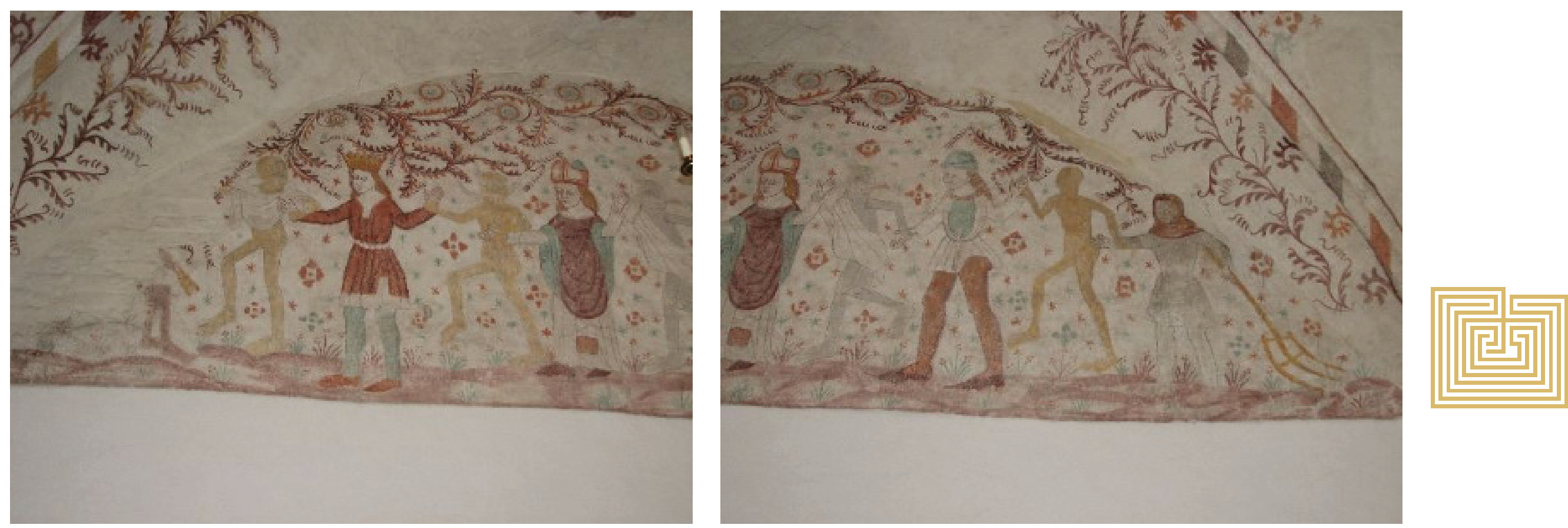

Kuvat 10a ja b. Kuolemantanssi, noin 1500, Norre Alslevin kirkko, Själlanti. Kuva: Kirsten Trampedach, Nationalmuseet Denmark.

on matala myssy. Nämä attribuutit viittaavat porvariin tai kauppiaaseen. ${ }^{63}$ Viimeinen selkeästi näkyvä hahmo on tumman päällysvaatteen ja vaalean kaavun perusteella tulkittavissa dominikaanimunkiksi. ${ }^{64}$ Viimeisin pari on lehterin peitossa, vain jalat näkyvät. Hahmon identiteetistä on hyvin vaikea sanoa mitään, vaikka Edgrenin mukaan kyseessä olisi naishahmo, jonka länsipuolella olisi vielä ollut lisäksi lapsi. ${ }^{65}$ Lapsen olemassaoloa on mahdotonta todistaa, sillä kuva on tästä kohdin täysin tuhoutunut. Fragmentaarinen hahmo on sen sijaan tunnistettavissa selkeästi naiseksi vaatteen helman ja kenkien perusteella: Vaaleaa hametta peittää sivuilta tummempi päällysvaate symmetrisesti ja teräväkärkiset kengät pilkottavat hameen helman alta. Tämä naisten vaatetuksen kuvaaminen toistuu samanlaisena esimerkiksi kuorin eteläseinän pyhää Annaa, neitsyt Mariaa ja Jeesusta sekä Elisabethin 
ja neitsyt Marian kohtaamista kuvaavissa aiheissa. ${ }^{66}$

Inkoon kirkossa esiintyvä Kuolemantanssi on eräänlainen lyhytversio, sillä se on alun perin koostunut luultavasti kymmenestä tanssiparista. ${ }^{67}$ Myös Tanskan Norre Alslevin Kuolemantanssi on tällainen lyhennelmä sisältäen neljä paria, eli kahdeksan tanssijaa, yhden fragmentaarisen hahmon lisäksi. ${ }^{68}$ Tällaiset pienennetyt kuolemantanssit osoittavat aiheen monimuotoisuuden - ne ovat seurakuntakirkkojen tarpeisiin mitoitettuja ja paikallisyhteisön hierarkiakäsitykseen ja maailmankuvaan sovitettuja esityksiä täysmittaisista Kuolemantansseista. Kuolemantanssin kuvauksia tarkasteltaessa huomaa, että aihe oli paitsi sovitettavissa erilasiin tiloihin ja ympäristöihin, myös esitettävien hahmojen yhteiskunnallinen asema ja statusta havainnollistavat vaatteet ja asusteet ovat olleet sovitettavissa ympäröivän sosiaaliseen kontekstin mukaiseksi. Siten jokainen kuolemantanssi kertoo myös tekopaikkansa ja -aikansa yhteisön sosiaalisesta rakenteesta.

Inkoon Kuolemantanssin maantieteellisesti lähin vastine on Tallinnan Nigulisten kirkossa sijaitseva Kuolemantanssi (n. 1500), joka on Bernt Notkelle attribuoitu myöhempi versio Lyypekissä (n. 1496, tuhoutunut 1942) sijainneesta Kuolemantanssista. ${ }^{69}$ Nämä kaksi maalausta eroavat kuitenkin huomattavasti keskenään. Pariisin, Lyypekin ja Tallinnan esimerkit ovat keskenään saman tyyppisiä kuolemantanssin kuvauksia: Jokaisen tanssiparin kohdalla on hahmon asemaa ja kohtaloa selittävä teksti, jolloin teoksen katsoja lukee teosta sekä kirjallisena että kuvallisena esityksenä. Inkoon Kuolemantanssi ei sisällä minkäänlaista tekstiosuutta nykymuodossaan, eikä sellaista todennäköisesti ole ollut alun perinkään. ja tTätä huomiota tukee se, että teksteistä ei ole minkäänlaisia jälkiä myöskään muissa Inkoon memento mori -aiheissa.

Tekstiä ja kuvaa yhdistelevä kuolemantanssi on lähtökohtaisesti edellyttänyt teoksen tarkastelijalta lukutaitoa: Kuolemantanssiin liittyvä teksti on oma proosallinen runoteoksensa, joka kommentoi kuvaa ja toimii sen kanssa vuorovaikutuksessa. Gertsmanin mukaan samanlainen kokemus ja tulkinta on voitu saavuttaa lukutaitoisen lukiessa muille tekstiä ääneen tai muistellen sitä. ${ }^{70}$ Tekstin lukeminen ääneen tai sisällön selostaminen on lisännyt kuolemantanssin tarkasteluun performatiivisen elementin. Gertsman esittää, että koko aiheen alkuperä on saattanut performanssissa, jolloin sen ensimmäiset ilmenemismuodot olisivat olleet erilaiset juhlakulkueet ja karnevaalit, joissa kuolemaa tai paholaista ovat esittäneet rooliasuihin pukeutuneet esiintyjät. ${ }^{71}$ Monissa kuolemantansseissa kuolleet hahmot soittavat soittimia kuin juhlakulkueessa ja itse tanssiminen viittaa myös karnevaaliin tai performanssiin. Kulkueita on saatettu myös näytellä osana kirkkovuoden juhlintaa tai karnevaalien yhteydessä. ${ }^{72}$ Tulkintaa kuolemantanssin performatiivisista ulottuvuuksista tukee myös esimerkiksi se, että Berliinin Kuolemantanssin kuolema-hahmot ovatkin itseasiassa eräänlaiseen luurankoasuun pukeutuneita henkilöitä ja Bretagnen Kermaria-an-Isquitin kappelin Kuolemantanssissa hahmoilla on yllään eläin- ja paholaisnaamioita. $^{73}$ Lukutaidottomille kirkossakävijöille kuolemantanssin hahmot ja tarina ovat saattaneetkin olla tutumpia suosituista mysteerinäytelmistä ja karnevaalikulkueista, kuin luettuna runoteoksena. ${ }^{74}$

Inkoon Kuolemantanssissa silmiinpistävä piirre on itse tanssiaktin viitteellisyys. Asetelma on muutenkin vähäeleinen, siitä puuttuu 
esimerkiksi kuolleiden villi askellus ja irvokkaat ilmeet sekä elävien inhoa kuvastavat ilmeet ja eleet tanssiparejaan kohtaan. Inkoossa elävät hahmot ovat liikkumattomia, molemmat jalat eteenpäin suunnattuina.

75 Kuolleiden hahmojen liikkeessä näkee eteenpäin vievän askeleen, mutta koko kompositio muistuttaa enemmän kulkuetta kuin tanssia. Tämä on varmasti osittain maalarin taitamattomuudesta johtuvaa kömpelyyttä, mutta toisaalta yksi kuolemantanssin versioista on voinut olla tekstitön ja valmiiksi yksinkertaistettu, maalarien mallikuvana käyttämä esitys.

Inkoon Kuolemantanssin visuaalisuus perustuu vastakkainasetteluun: Arvokkaasti, sosioekonomisen asemansa mukaan esiintyvät ja puetut elävät hahmot kulkevat käsi kädessä pelkkään hartioille vedettyyn käärinliinaan pukeutuneiden ruumiiden kanssa. Inkoon kuolleet hahmot eivät varsinaisesti muistuta meille tuttua luurankona kuvattua kuolemaa, vaan ovat tumman värisiä, virnistäviä inmishahmoja. Näille hahmoille löytyy kuitenkin vastineensa muista kuolemantansseista: Keskiajalla luurankoa yleisempi kuoleman personifikaatio on lahoavaan vaatteeseen tai käärinliinaan pukeutunut mätänevä, tummaksi tai harmaaksi muuttunut ruumis. ${ }^{76}$ Näin tarkasteltuna Inkoon kuolleet tanssijat näyttäytyvät osana kuvallista traditiota, jossa kutakin elävää johdattaa makaaberissa mätänemisen prosessissa oleva ruumis. Tämä hahmo myös tulkittavissa elävän tanssiparin omaksi, kuolleeksi ja maatuvaksi kehoksi. ${ }^{77}$

\section{Kuolema ja hyvä elämä}

Vaikka kuolemantanssia ei keskiaikaisen Ruotsin alueelta muita löydykään, ovat muut memento mori -kuvat yleisiä Ruotsin alueen keskiaikaisissa kirkoissa. Suomen alueen kirkoissa ei tämän hetkisen tutkimustiedon valossa ole säilynyt yhtään näiden aiheiden esimerkkiä Inkoon lisäksi, mutta tämä saattaa johtua aineiston huonosta säilyneisyydestä. Vastaavia kuvia on saattanut olla myös Suomen alueen kirkoissa keskiajalla. Kivikirkkojen asehuoneita, aiheen mahdollisia sijoituspaikkoja, on purettu uudella ajalla. Näin on tehty esimerkiksi Siuntion ja Espoon kirkoissa. ${ }^{78}$ Tämän lisäksi kaikki keskiaikaisissa puukirkoissa sijainneet maalaukset ovat hävinneet rakennusten mukana. On siis täysin mahdollista, että memento mori -kokonaisuuksia tai jopa kuolemantansseja on kuvattu muuallakin. ${ }^{79}$
Kuolemantanssi on liitetty tutkimuksessa hansakaupan yhteydessä tapahtuneeseen kulttuurivaihtoon. Bernt Notken Lyypekin Mariankirkkoon maalaama Kuolemantanssi olisi mahdollisesti innoittanut muissakin hansakaupungeissa vastaavaan hankintaan, kuten on todennäköistä Tallinnan Kuolemantanssin kohdalla. ${ }^{80}$ Myös Inkoon Kuolemantanssin innoittajaa tai sen esimerkkiä on haettu Tallinnan Kuolemantanssista. ${ }^{81}$ Inkoossa sijaitsi satama keskiajalla ja Tallinnaan oli myös tiiviit yhteydet Inkoosta 26 kilometrin päässä sijaitsevasta Raaseporin linnoituksesta. Hyvin todennäköisesti esimerkiksi Tallinnan ja Raaseporin väliä kulkeneet kauppiaat ovat saattaneet nähdä Tallinnan Kuolemantanssin, mutta näiden kahden kuvallisilla esikuvilla ei ole merkittävää yhteyttä. ${ }^{82}$ Pidän kuitenkin mahdollisena, että Kuolemantanssi, sen mallikuvat tai koko maalauskokonaisuuden tekijät olisi hankittu Inkooseen hansakauppiaiden tai Tallinnan -yhteyksien myötävaikutuksella.

Aikaisemmassa tutkimuksessa kuolemantanssin maalaamiselle juuri Inkoon kirkkoon on etsitty motivaatiota historian tapahtumista. Helena Edgren esittää, että Inkoon Kuolemantanssi liittyisi mahdollisesti alueelliseen 
ruttoepidemiaan tai sitten kuva-aiheesta oli tullut jo muoti-ilmiö 1500 -luvun alussa. ${ }^{83}$ Cora Diel lisää, että Kuolemantanssi saattoi kuvastaa myös sodan pelkoa, erityisesti ottaen huomioon Inkoossa tapahtuneen tanskalaisten hävityksen vuonna $1509 .{ }^{84}$ Kuolemantanssin liittäminen tiettyihin yhteisöä traumatisoineisiin tapahtumiin voidaan mielestäni nähdä heijastumana aikaisemman tutkimustradition käsityksestä kuolemantanssin asemasta ruttoa symboloivana aiheena. ${ }^{85}$ Kuolemantanssin tilaaminen juuri Inkooseen ei kuitenkaan välttämättä liity juuri keskiaikaisen Inkoon yhteisön kokemiin kohtaamisiin kuoleman ja hävityksen kanssa.

Kun otetaan huomioon myöhäiskeskiajan visuaalisen kulttuurin suhde makaaberiin kuolemaan ja näkökulma kuolemantanssista laajana kulttuuri-ilmiönä, pidän todennäköisempänä sitä, että koko memento mori -kokonaisuus on tehty Inkooseen osana kirkon seinämaalausten ajanmukaista kokonaisuutta ja tukemaan sanomaa katoavaisesta elämästä ja ikuisen sielun moraalisesta hyvinvoinnista. Samalla seinällä sijainnut Kenkä-Ella tukee tulkintaa hyvän elämän ja kuoleman pohtimiseen muistuttavasta kuvakokonaisuudesta. Rutto ja muut taudit olivat 1500-luvun alussa Itämeren rannoilla todellisia uhkia, mutta myöhäiskeskiajan yhteisön elämään ja kuolemaan vaikuttivat myös sodat, suuri lapsikuolleisuus sekä maatalousyhteiskuntaa aika ajoin vaivanneet katovuodet. Kuolema oli usein äkillinen ja pelätty, mutta tuttu vieras.

Vaikka Suomessa ei ole säilynyt muita vastaavia kokonaisuuksia, on Inkoon memento mori vertailtavissa yleiseurooppalaiseen myöhäiskeskiaikaiseen kuvatraditioon sisällöltään. Kuva-aiheilla on selkeä tarkoitus ja allegorinen viestinsä. On kiinnostavaa, että Inkoossa juuri nämä kuva-aiheet on liitetty yhteen. Kuvanauhaa vasemmalta oikealle lukiessa Kuolema sahaamassa puuta, Elämänpyörä ja Kuolemantanssi muodostavat kuvanauhan, jossa aiheet paitsi rinnastuvat toisiinsa, muodostavat myös inmisen elinkaarta kuvaavan kokonaisuuden. Kuvasarja alkaa puussa istuvasta nuorukaisesta, jonka kuolema vasta odottaa tai häälyy - määrittelemättömän ajan päässä. Keskimmäinen kuva, Elämänpyörä kuvaa ihmisen elämänvaiheita - nuoruutta, keski-ikää ja vanhuutta sekä kuolemaa. Kuolemantanssi, kuolemisen prosessi, alkaa tämän aiheen jälkeen. Kulkueen kulkusuunta on kohti itää ja kuoria, taivaan ja Viimeisen tuomion suuntaa. Näin tarkasteltuna Inkoon memento mori -kokonaisuus muodostaa kerronnallisen, inmisen maallista elämää kuvailevan kokonaisuuden. Kuvien allegorioista välittyy kuoleman alituinen läsnäolo ja uhka, joka oli realiteetti keskiajan inmiselle. Samalla kuvat muistuttavat kaiken aineellisen katovaisuudesta, joka ohjaa katsojaa pohtimaan ei-katoavaista - sielun hyvinvointia ja hyvää elämää.

\section{Viitteet}

1 Artikkeli on laadittu Koneen Säätiön rahoittaman väitöskirjahankkeeni puitteissa. Kiitän erityisesti ohjaajiani Elina Räsästä sekä Anu Lahtista arvokkaasta tuesta ja palautteesta sekä Visa Immosta ja Leena Valkeapäätä avusta lähteiden ja kirjallisuuden kanssa. Lisäksi haluan kiittää referee-lausujiani hyödyllisestä kritiikistä, joka vei artikkelikäsikirjoitusta oleellisesti eteenpäin.

2 Wennervirta, Ludvig, Suomen Keskiaikainen Kirkkomaalaus. Porvoo: WSOY, 1937. 132-136; Nilsén, Anna, Program och funktion i senmedeltida kalkmåleri: Kyrkmålningar i Mälarlandskapen och Finland 1400-1534. Stockholm: Kungl. Vitterhets Historie och Antikvitets Akademien, 1986. 412; Riska, Tove, Ars - Suomen Taide 1. Espoo: Weilin + Göös, 1987. 166; Edgren, Helena, "The Dance of Death in Inkoo: A Medieval Church Painting as a Source of Local History". (Ed.) Krötzl, Christian 
\& Masonen, Jaakko. Quotidianum Fennicum: Daily Life in Medieval Finland. Krems: Gesellschaft zur Erforschung der materiellen Kultur des Mittelalters, 1989. 89-100; Diel, Cora, "Ein Abglanz Notkes? Der Totentanz Von Inkoo Im Hanseatischen Kontext." Neuphilologische Mitteilungen, vol.101/ 2, 2000.

145-158. Inkoon Kuolemantanssin mainitsee myös Gertsman, Elina, The Dance of Death in the Middle Ages: Image, text, performance. Turnhout: Brepols, 2010. 166.

3 Emil Nervanderin laatima Inkoon maalausten restaurointikertomus vuodelta 1896, Inkoon kirkko, Historian topografinen arkisto, Museovirasto. Aiheen mainitsee myös Wennervirta, Suomen Keskiaikainen Kirkkomaalaus. 136.

4 Määrittelen tässä artikkelissa keskiajan Ruotsin valtakunnan kattavan aikarajauksen 800 -luvulta reformaation alkuun (noin 1530) asti. Keskiajan Ruotsista lisää kts. Lindkvist, Tomas \& Sjöberg, Maria, "Vad var Sverige?" Det svenska samhället 800-1720 - Klerikernas och adelns tid. Lund: Studentlitteratur, 2009. 23-24.

5 Emil Nervanderin laatima Inkoon maalausten restaurointikertomus vuodelta 1896, Inkoon kirkko, Historian topografinen arkisto, Museovirasto. 6 Helena Edgren kirjoitti memento mori -maalausten paljastuttua kirkon kunnostustöissä (1987-1988) aiheesta artikkelin Helsingin Sanomiin. "Kuolema tanssii Inkoossa". Helsingin Sanomat. 24.12.1988. Edgrenin vuonna 1989 julkaistu tieteellinen artikkeli käsittelee kuitenkin ainoastaan Inkoon Kuolemantanssia. Korjaustöistä kts. Järventaus Esko, 1988, Inkoon kirkko korjausohjelma, https:// www.kyppi.fi/to.aspx?id=117.4525 Kulttuuriympäristön tutkimusraportit, Inkoo, MV.; Alakärppä, Raimo. Inkoon kirkon maalaukset, konservointi 1987-88. Kulttuuriympäristön tutkimusraportit, Inkoo, MV. https://www.kyppi.fi/to.aspx?id=117.4022.

7 Kuolema sahaamassa puuta sekä Elämänpyörä on mainittu lyhyesti aiemmassa tutkimuksessa kts. Hiekkanen, Suomen keskiajan kivikirkot. Helsinki:
Suomalaisen Kirjallisuuden Seura, 2007. 434; Räsänen, Elina, "Uskokoon ken tahtoo. Juhani Harri ja esineiden maailmankatsomus". Juhani Harri. Tampere: Sara Hildénin taidemuseo, 2019.46. 8 Wennervirta, Suomen Keskiaikainen Kirkkomaalaus. 132-136; Nilsén, Program och funktion i senmedeltida kalkmåleri: Kyrkmålningar Mälarlandskapen och Finland 1400-1534. 412; Riska, Ars - Suomen Taide 1. 166.

9 Ikonografiasta ja kontekstualisoinnista taidehistorian menetelmänä kts. Räsänen, Elina, "The Panopticon of Art History: Some Notes on Iconology, Interpretation, and Fears". (Ed.) Liepe, Lena. Locus of Meaning in

Medieval Art: Iconography, Iconology and Interpreting the Visual Imagery of the Middle Ages. Studies in Iconography: Themes \& Variations. Medieval Institute Publications, 2018. 46, 50-51.

10 Hiekkanen, Suomen keskiajan kivikirkot. 432-433. 11 Myös Vaasan rauniokirkosta on löydetty maalausfragmentteja, jotka ovat mahdollisesti saman ryhmän toteuttamia. Riskan mukaan myös Rauman fransiskaanikonventin kuorimaalaukset kuuluisivat samaan ryhmään. Riska, Ars - Suomen Taide 1. 161. Rauman maalausten kuuluminen samaan ryhmään Inkoon, Espoon ja Siuntion kanssa ei ole yksiselitteistä ja kaipaa lisätutkimusta. Fält, Katja, "Taivaan valtiaat Rauman Pyhän Ristin kirkon keskiaikaisissa maalauksissa". (Toim.) ljäs, Miia \& Lahtinen, Anu. Risti ja lounatuuli: Rauman seurakunnan historia keskiajalta vuoteen 1640 Helsinki: Suomalaisen Kirjallisuuden Seura, 2015. 12 Riska, Ars - Suomen Taide 1. 161. Myös Ilola, Merja, 2008. Siuntion kirkon keskiaikaisten maalausten ikonografia ja kuvaohjelma. Pro gradu -tutkielma. Helsingin yliopisto.

13 On myös mahdollista, että maalari on kokenut silmien maalaamisen haastavaksi. Todennäköisesti näissä kirkoissa on kuitenkin työskennellyt useita eri maalareita myös henkilöhahmojen toteutuksessa ja kyse onkin enemmän vakiintuneesta tyylistä toteuttaa inmishahmo. Kts. Riska, Ars - Suomen Taide 1. 166-
167 ja llola, Siuntion kirkon keskiaikaisten maalausten ikonografia ja kuvaohjelma. 85-86.

14 Edgren, "The Dance of Death in Inkoo: A Medieval Church Painting as a Source of Local History". 89, 98-99; Diel, "Ein Abglanz Notkes? Der Totentanz Von Inkoo Im Hanseatischen Kontext.". 157; Hiekkanen,

Suomen keskiajan kivikirkot. 435. Kaikki edelliset ehdottavat maalausten ajankohdaksi vuonna 1509 tapahtuneen tanskalaisten hyökkäyksen jälkeisiä

korjaustöitä ja kirkon laajennusta.

15 Siuntion, Espoon ja Inkoon kanssa

todennäköisesti samoihin aikoihin toteutetut Rauman fransiskaanikonventin kirkon kuorin maalaukset on ajoitettu Arvid Kurjen piispuuden ajalle 1510-1522 ja niiden ajoitukseksi ilmoitetaan yleensä noin 1510, vaikka myös noin vuosi 1520 on täysin mahdollinen. Kts. Ilola, Siuntion kirkon keskiaikaisten maalausten ikonografia ja kuvaohjelma. 90. Ajoituksista myös Nygren, Olga Alice, En medeltida frälsningsspegel. Helsingfors, 1957. 179.

16 Kunnostustöiden tarkoituksesta Pastori G.

Boijerin kirje professori J.R. Aspelinille 1.4.1894; tarkastuskertomus E. Nervanderilta Arkeologiselle komissiolle 6.5.1894; tutkimuskertomus E.

Nervanderilta Arkeologiselle komissiolle 26.9.1894. Inkoon kirkko, Historian topografinen arkisto, MV.; Armas Lindgrenin akvarellit ja kalkeeraukset Inkoon kirkon seinämaalauksista, Inkoon kirkko, Historian kuvakokoelma, MV.

17 Tutkimuskertomus E. Nervanderilta Arkeologiselle komissiolle 26.9.1894 sekä kopio Armas Lindgrenin laatimasta kuva-aiheiden kartasta vuodelta 1894 Inkoon kirkko, Historian topografinen arkisto, MV; myös Armas Lindgrenin laatimat akvarellit Inkoon seinämaalauksista. Inkoon kirkko, Historian kuvakokoelma, MV.

18 Järventaus, Esko, Inkoon kirkko korjausohjelma, https://www.kyppi.fi/to.aspx?id=117.4525 Inkoo,

Kulttuuriympäristön tutkimusraportit, MV.

19 Korpiola, Mia \& Lahtinen, Anu, "Cultures of Death and Dying in Medieval and Early Modern Europe: 
An Introduction" (Ed.) Korpiola, Mia \& Lahtinen, Anu, Cultures of Death and Dying in Medieval and Early Modern Europe. Helsinki Collegium for Advanced Studies, 2015. 1-28. Kuoleman käytännön järjestelyistä kts. Korpiola, Mia \& Lahtinen, Anu, Planning for Death: Wills and Death-Related Property Arrangements in Europe, 1200-1600. Boston: BRILL, 2018

20 Binski, Paul. Medieval Death : Ritual and Representation. London: British Museum Press, 1996. passim; Korpiola \& Lahtinen, "Cultures Death and Dying in Medieval and Early Modern Europe: An Introduction". 7-11. Ars Moriendista kts esim. Fallberg Sundmark, Stina,"Hyvä elämä, hyvä kuolema". (Toim.) Kanerva, Kirsi. \& Lamberg, Marko. Hyvä elämä keskiajalla. Helsinki: Suomalaisen Kirjallisuuden Seura, 2014.

21 Oosterwijk, Sophie, "'This Worlde Is but Pilgrimage' Mental Attitudes in/to the Medieval Danse Macabre." (Ed.) Katajala-Peltomaa, Sari, and Susanna Niiranen. Mental (Dis)Order in Later Medieval Europe: Vol. 12. Leiden: BRILL, 2014.198204.

22 Binski, Medieval Death : Ritual and

Representation. 21-26; Melin, Pia. Fåfängans Förgänglighet: Allegorin Som Livs- Och Lärospegel Hos Albertus Pictor. Stockholm: Stockholmia, 2007. 135; Kanerva, Kirsi \& Lamberg, Marko, 2014. "Johdanto: Hyvä elämä ja keskiajan syksy." (Toim.) Kanerva, K. \& Lamberg, M. Hyvä elämä keskiajalla. Helsinki: Suomalaisen Kirjallisuuden Seura. 15-16. Vaikutuksesta kirkkojen maalauksiin ja lahjoituskäytäntöihin Tuhkanen, Tuija. In memoriam sui et suorum posuit' : lahjoittajien muistokuvat Suomen kirkoissa 1400-luvulta 1700-luvun lopulle. Åbo Akademis förlag: 2005. 41-49.

23 Kanerva \& Lamberg, "Johdanto: Hyvä elämä ja keskiajan syksy". 25-27; Palmi-Felin, Salla, " Uusi työ' moraalin uhkana" (Toim.) Kanerva, Kirsi \& Lamberg, Marko. Hyvä elämä keskiajalla. Helsinki: Suomalaisen Kirjallisuuden Seura, 2014. 172-174.
24 Melin, Fåfängans Förgänglighet: Allegorin Som Livs- Och Lärospegel Hos Albertus Pictor. 67-68.; Lamberg, Marko, 2014. "Ruumiin ehtyvät voimat". (Toim.) Kanerva, Kirsi \& Lamberg, Marko. Hyvä elämä keskiajalla. Helsinki: Suomalaisen Kirjallisuuden Seura. 142-143.

25 Binski, Medieval Death : Ritual and

Representation. 134-163. Gertsman, The Dance of Death in the Middle Ages: Image, text, performance. 23-40. Oosterwijk, "'This Worlde Is but a Pilgrimage" Mental Attitudes in/to the Medieval Danse Macabre". 200-202.

26 Mielikuva kuolemantanssista katastrofien, kuten ruton yhteydessä esiintyvänä ilmiönä perustuu pitkälti Johan Huizingan esittämään teoksessaan Keskiajan syksy. Uusi tutkimus on kuitenkin todennut, että 1400-luvun ja myöhäisemmät ruttoepidemiat olivat sosiaalisilta vaikutuksiltaan eri tyyppisiä kuin 1300-luvun puolivälin musta surma. Philippe Ariésin mukaan makaaberit teemat korostuivat ylipäätään yksilön kuoleman noustessa kiinnostuksen kohteeksi myöhäiskeskiajalla. Gertsman, Elina, "Visual Space and the Practice of Viewing: The Dance of Death at Meslay-le-Grenet". Religion and the Arts, 9 (1-2), 2005. 33; Gertsman, The Dance of Death in the Middle Ages: Image, text, performance. 23-42; Oosterwijk, "'This Worlde Is but a Pilgrimage'

Mental Attitudes in/to the Medieval Danse Macabre". 198-204. Kts. myös Huizinga, Johan, Keskiajan syksy: Elämän- ja hengenmuotoja Ranskassa ja Alankomaissa 14. ja 15. vuosisadalla. Helsinki: WSOY:1951, sekä Ariès, Philippe \& Ranum, P. M. Western attitudes toward death: From the Middle Ages to the present. Baltimore: Johns Hopkins University Press. 27-52.

27 Binski, Medieval Death : Ritual and

Representation. 125

28 Edgren, Helena, "De skrivande djävlarna i Finlands medeltida kyrkor". Finskt museum, 1981. 86. 54-68; Edgren, Helena., "Hästhandel i Finlands medeltida kyrkor". Finskt museum, 92, 1985
70-80; Nilsén, Program och funktion i senmedeltida kalkmåleri: Kyrkmålningar i Mälarlandskapen och Finland 1400-1534. 422-425; Fält, Katja," Women and Demons in the Late Medieval Wall Paintings in the Church of Espoo (Finland)". Mirator 18:1/2017. 29 Nilsén, Program och funktion i senmedeltida kalkmåleri: Kyrkmålningar i Mälarlandskapen och Finland 1400-1534. 89, 97, 109; Memento mori -kuvien sijoittelu asehuoneeseen kts. Melin, Fåfängans Förgänglighet: Allegorin Som LivsOch Lärospegel Hos Albertus Pictor. 72-75.

Suomen alueella moraliteettikuvia on myös usein sijoitettu asehuoneeseen, esim. Lohjan, Hattulan, Hollolan, Taivassalon ja Rymättylän kirkoissa tai vaihtoehtoisesti länsipäädyn sisäänkäynnin alueelle, kuten Siuntiossa, Espoossa ja Hattulassa.

30 Meslay-le-Grenetistä Gertsman, "Visual Space and the Practice of Viewing: The Dance of Death At Meslay-le-Grenet.". 11า-12 ja Beramista Vignjević, Tomislav, "The Istrian Danse Macabre" (ed.) Knöll, Stefanie, and Sophie Oosterwijk. Mixed Metaphors The Danse Macabre in Medieval and Early Modern Europe. Cambridge Scholars Publishing, 2011. 31 Tutkimuskertomus E. Nervanderilta Arkeologiselle komissiolle 26.9.1894 sekä kopio Armas Lindgrenin laatimasta kuva-aiheiden kartasta vuodelta 1894 Inkoon kirkko, Historian topografinen arkisto, MV.;

Myös A. Lindgrenin laatimat akvarellit Inkoon maalauksista. Inkoon kirkko, Historian kuvakokoelma, MV.

32 Fält, "Women and Demons in the Late Medieval Wall Paintings in the Church of Espoo (Finland)". 19-20.

33 Nervanderin muistiinpanot aiheesta eivät anna täysin tarkkaa kuvaa aiheen sijainnista.

Tutkimuskertomus E. Nervanderilta Arkeologiselle komissiolle 26.9.1894. Inkoon kirkko, Historian topografinen arkisto, MV.

34 Melin, Fåfängans Förgänglighet: Allegorin Som Livs- Och Lärospegel Hos Albertus Pictor. 67-72; Räsänen, Elina. "Advocating, Converting, and

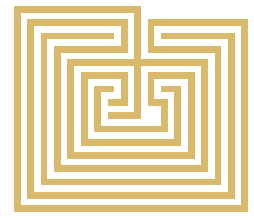


Torturing: Images of Jews (and Muslimized Pagans) in the Kalanti Altarpiece." Fear and Loathing in the North. Berlin, München, Boston: DE GRUYTER, 2015. 305-306.

35 Palmi-Felin, " 'Uusi työ' moraalin uhkana".

\section{2-174.}

36 Melin, Fåfängans Förgänglighet: Allegorin Som Livs- Och Lärospegel Hos Albertus Pictor. 105. 37 Ibidem., 98-99,105.

38 Nilsén, Program och funktion i senmedeltida kalkmåleri: Kyrkmålningar i Mälarlandskapen och Finland 1400-1534, 40, 89, 91, 97, 109, 143.

Tierpin ja Vendelin kirkoissa aihe on runkohuoneen eteläseinällä, kts. Ibidem. 146, 161.

39 Melin, Fåfängans Förgänglighet: Allegorin Som Livs- Och Lärospegel Hos Albertus Pictor. 102.

40 Käännös Lamberg, Marko, "Barlaamin ja Josafatin legenda". (Toim.) Kauko, Mikko et al. Naantalin luostarin kirja. Helsinki: Suomalaisen Kirjallisuuden Seura, 2017. 213

41 Käännös kirjoittajan. Nilsén, Program och funktion i senmedeltida kalkmåleri: Kyrkmålningar i Mälarlandskapen och Finland 1400-1534, 146. Myös Melin, Fåfängans Förgänglighet: Allegorin Som LivsOch Lärospegel Hos Albertus Pictor. 101.

42 Sears, Elizabeth, The ages of man: Medieval interpretations of the life cycle. Princeton, $\mathrm{NJ}$ :

Princeton University Press, 1986. 144; Melin,

Fåfängans Förgänglighet: Allegorin Som Livs- Och Lärospegel Hos Albertus Pictor. 76; Lehtonen,

Tuomas, Fortuna, money, and the sublunar world:

Twelfth-century ethical poetics and the satirical poetry of the Carmina Burana. Diss. Bibliotheca historica, 9. Helsinki: Finnish Historical Society, 1995. 73-74.

43 Lehtonen, Fortuna, money, and the sublunar

world: Twelfth-century ethical poetics and the satirical poetry of the Carmina Burana, 77, 94.

44 Ibidem., 73.

45 lbidem., 93.

46 Sears, The ages of man: Medieval interpretations of the life cycle. 144; Lehtonen, Fortuna, money, and the sublunar world: Twelfth-century ethical poetics and the satirical poetry of the Carmina Burana. 93-94.

47 Melin, Fåfängans Förgänglighet: Allegorin Som Livs- Och Lärospegel Hos Albertus Pictor. 89.

48 Sears, The ages of man: Medieval interpretations of the life cycle. 151-153.

49 Vignjević, "The Istrian Danse Macabre". 300. 50 Gertsman, Elina, "The Dance of Death in Reval (Tallinn): The Preacher and His Audience". Gesta, 42(2), 2003. 143.

51 Binski, Medieval Death : Ritual and

Representation. 156-157; Oosterwijk, "Dance,

Dialogue and Duality: Fatal Encounters in the

Medieval Danse Macabre." (ed. )Oosterwijk, Sophie

\& Knöll, Stephanie. Mixed Metaphors: The Danse

Macabre in Medieval and Early Modern Europe.

Newcastle-upon-Tyne: Cambridge Scholars Publisher, 2011. 31.

52 Gertsman, "The Dance of Death in Reval (Tallinn):

The Preacher and His Audience". 143. Inkoosta kts.

Edgren, "The Dance of Death in Inkoo: A Medieval

Church Painting as a Source of Local History". 97.

53 Joidenkin saksankielisen alueen kuolemantanssi

-aiheisten painotuotteiden ja seinämaalausten

keskinäinen vertailu kts. Warda, Susanne.

Memento Mori: Bild Und Text in Totentänzen Des

Spätmittelalters Und Der Frühen Neuzeit. Köln:

Böhlau, 2011., Anhang.

54 Binski, Medieval Death : Ritual and

Representation. 157

55 Gertsman, "The Dance of Death in Reval (Tallinn): The Preacher and His Audience". 149

56 Edgren, "The Dance of Death in Inkoo: A Medieval Church Painting as a Source of Local History", 90;

Diel, "Ein Abglanz Notkes? Der Totentanz Von Inkoo

Im Hanseatischen Kontext." 150. Nilsénin mukaan

hahmo olisi porvari, mutta porvarin sijoittamiselle

piispan ja aatelisen väliin tuskin olisi mitään syytä

Nilsén, Program och funktion i senmedeltida

kalkmåleri: Kyrkmålningar i Mälarlandskapen och
Finland 1400-1534. 421

57 A. Lindgrenin akvarelli 1984. Inkoon kirkko.

Historian kuvakokoelma, MV.

58 Edgrenin mukaan tässä kohdin olisi ollut jo keskiajalla ikkuna-aukko, joten kulkue ei olisi voinut jatkua itään päin. Edgren, "The Dance of Death in

Inkoo: A Medieval Church Painting as a Source of Local History", 96.

59 Tämän tulkinnan tekevät myös Nilsén, Program och funktion i senmedeltida kalkmåleri: Kyrkmålningar i Mälarlandskapen och Finland 1400-1534. 421.

Edgren, , "The Dance of Death in Inkoo: A Medieval Church Painting as a Source of Local History". 90;

Diel, "Ein Abglanz Notkes? Der Totentanz Von Inkoo Im Hanseatischen Kontext", 150.

60 Edgren, , "The Dance of Death in Inkoo: A

Medieval Church Painting as a Source of Local

History". 90; Diel, "Ein Abglanz Notkes? Der

Totentanz Von Inkoo Im Hanseatischen Kontext". 151.

$61 \mathrm{~A}$. Lindgrenin tekemä kalkeeraus länsipäädyn

maalauksista. Inkoon kirkko, Historian kuvakokoelma, MV.

62 Diel, "Ein Abglanz Notkes? Der Totentanz Von

Inkoo Im Hanseatischen Kontext". 152.

63 Kauppias -tulkintaan päätyy myös Diel, "Ein

Abglanz Notkes? Der Totentanz Von Inkoo Im

Hanseatischen Kontext". 153.

64 Edgren, "The Dance of Death in Inkoo: A Medieval Church Painting as a Source of Local History". 90.

65 Ibidem, 95.

66 Räsänen, Elina, Ruumiillinen esine, materiaalinen suku: Tutkimus Pyhä Anna itse kolmantena -aiheisista keskiajan puuveistoksista Suomessa. Suomen Muinaismuistoyhdistys, 2009. 91-92.

67 Inkoon Kuolemantanssin alkuperäisestä pituudesta ei ole täyttä varmuutta. Edgrenin mukaan se olisi päättynyt nykyistä vain hieman pidemmälle ja rajoittunut pohjoisseinän ikkunaan ennen sakastia. Edgren, "The Dance of Death in Inkoo: A Medieval Church Painting as a Source of Local History".96. 68 Danmarks kirker VIII (bind 2). København: 
Nationalmuseet, 1951. 1196

69 Gertsman, "The Dance of Death in Reval (Tallinn):

The Preacher and His Audience" 143. Nigulisten

Kuolemantanssista myös Lumiste, Mai, Tallinna

surmatants. Tallinn: Kunst, 1971.

70 Gertsman, "The Dance of Death in Reval

(Tallinn): The Preacher and His Audience". 146-

147. Kuolemantanssin olemuksesta eräänlaisena

kuvan, tekstin ja saarnan yhteisteoksena kts.

myös Gertsman, "The Dance of Death in Reval

(Tallinn): The Preacher and His Audience". 150-151;

Gertsman, The Dance of Death in the Middle Ages:

Image, text, performance 45-47.

71 Gertsman, The Dance of Death in the Middle

Ages: Image, text, performance. 35. Kts. myös

Eustace, Frances \& King, Pamela, "Dances of the

Living and the Dead: A Study of Danse Macabre

Imagery within the Context of Late Medieval Dance

Culture". (Ed.) Knöll, Stephanie. \& Oosterwijk, Sophie.

Mixed Metaphors: The Danse Macabre in Medieval

and Early Modern Europe. Newcastle upon Tyne:

Cambridge Scholars Publishing, 2011. 47-48.

72 Gertsman, The Dance of Death in the Middle

Ages: Image, text, performance. 80, 93-94.

73 Kuvien ja performanssin yhteydestä Räsänen,

"Advocating, Converting, and Torturing: Images

of Jews (and Muslimized Pagans) in the Kalanti

Altarpiece". 306

74 Inkoon ja Norre Alslevin tavoin myös Bretagnen Kermaria-an-Isquitin kappelin Kuolemantanssissa noin vuodelta 1490 hahmot askeltavat jäykästi ja koko kulkue on vailla selkeää suuntaa. Tästäkin esimerkistä puuttuu kokonaan tekstiosio. Gertsman, The Dance of Death in the Middle Ages: Image, text, performance. 80, 93-94.

75 Gertsman, The Dance of Death in the Middle Ages: Image, text, performance. 22-23,33; Oosterwijk, "Dance, Dialogue and Duality: Fatal Encounters in the Medieval Danse Macabre". 14-16. 76 Tämän mainitsee myös Wennervirta, Suomen Keskiaikainen Kirkkomaalaus. 134. Kuolleiden hahmojen olemus on tutkimuksessa keskusteltu kysymys - ovatko ne kuoleman personifikaatioita, vai elävien tanssijoiden omia, kuolleita ruumiita. Kts. Oosterwijk, "Dance, Dialogue and Duality: Fatal Encounters in the Medieval Danse Macabre". 16; Warda, Susanne, "Dance, Music and Inversion." (Ed.) Knöll, Stephanie. \& Oosterwijk, Sophie. Mixed Metaphors: The Danse Macabre in Medieval and Early Modern Europe. Newcastle upon Tyne:

Cambridge Scholars Publishing, 2011. 97-99.

77 Espoon kirkon asehuone on purettu 1821-1823 ja Siuntion 1823 tulipalon jälkeen. Hiekkanen, Suomen keskiajan kivikirkot. 429 ja 476.

78 Tästä myös Riska, Ars - Suomen Taide 1. 166

79 Gertsman, "The Dance of Death in Reval (Tallinn): The Preacher and His Audience". 144; Diel, "Ein Abglanz Notkes? Der Totentanz Von Inkoo Im Hanseatischen Kontext". 146-147.

80 Edgren, "The Dance of Death in Inkoo: A Medieval Church Painting as a Source of Local History". 96.

81 Tähän tulokseen päätyy myös Diel, "Ein Abglanz Notkes? Der Totentanz Von Inkoo Im Hanseatischen Kontext". 150.

82 Edgren, "The Dance of Death in Inkoo: A Medieval Church Painting as a Source of Local History". 98. 83 Tästä myös Diel, "Ein Abglanz Notkes? Der Totentanz Von Inkoo Im Hanseatischen Kontext". 157. 84 Binski, Medieval Death : Ritual and

Representation. 126-133. Kuolemantanssi

eräänlaisena votiivikuvana tai ruttomuistomerkkinä on toisaalta myös relevantti tutkimusnäkökulma ja erityisesti Lyypekin Kuolemantanssiin on liitetty ajatus, että se olisi muistomerkki ruton uhreille ja lisäksi toiminut varoituksena tulevista epidemioista, jotta inmiset muistaisivat tartuntatautien vaarat.

Freytag, Hartmut, Der Totentanz der Marienkirche in Lübeck und der Nikolaikirche in Reval (Tallinn): Edition, Kommentar, Interpretation, Rezeption. Köln: Böhlau, 1993. 16
FM, väitöskirjatutkija Janika Aho tutkii

Helsingin yliopistossa Suomen keskiai-

kaisia (1420-1520) ammattimaalareiden

kirkkomaalauksia ja niiden merkityksiä

keskiajan yhteisöille. Väitöstutkimusta ra-

hoittaa Koneen Säätiö.

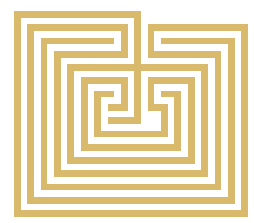

